\title{
The Eastern Boundary of the Subtropical North Atlantic
}

\author{
M. ARHAN \\ Laboratoire de Physique des Océans, Unité Mixte CNRS-IFREMER-Université, IFREMER/Centre de Brest, Plouzané, France

\section{A. COLIN DE VERdière} \\ Laboratoire de Physique des Océans, Unité Mixte CNRS-IFREMER-Université, Université de Bretagne Occidentale, Brest, France
}

\author{
L. MEMERY
}

LODYC-Université Pierre et Marie Curie, Paris, France

(Manuscript received 17 November 1992, in final form 22 September 1993)

\begin{abstract}
A quasi-meridional hydrographic section carried out between $60^{\circ}$ and $20^{\circ} \mathrm{N}$ offshore from the European and African continental slopes is analyzed in terms of water masses and zonal transports in and out of the eastern boundary. Outstanding features of the meridional distribution of water masses are focused on, such as the transition between North Atlantic and South Atlantic Central Waters at $20^{\circ}-25^{\circ} \mathrm{N}$, the properties and anticyclonic circulation of the Rockall Channel mode water, and the northern boundary of the large-scale Mediterranean Water plume at about $50^{\circ} \mathrm{N}$. An eastward transport of about $11 \times 10^{6} \mathrm{~m}^{3} \mathrm{~s}^{-1}$ is found to enter the eastern boundary layer at densities lower than 27.25 and feed southward alongshore currents. The relation of the incoming transport to the water mass distribution and its eventual splitting into several outflowing components are discussed. Apart from the downward entrainment of upper water known to occur in the Gulf of Cadiz, there is no sign of the so-called "eastern boundary ventilation" mechanism in the central water density range. Yet a significant transport is found to escape the winter mixed layer toward the interior of the subtropical gyre, suggesting the horizontal southward currents across the sloping bottom of the mixed layer to be the main cause of ventilation at the eastern boundary.
\end{abstract}

\section{Introduction}

The attention of physical oceanographers has in the past been more attracted by western boundaries of oceanic basins than by their eastern counterparts. This has been a quite natural inclination considering the intensities of currents on both sides, yet the relative abandon of eastern boundaries is surprising, as many large-scale circulation models are integrated from the east. It looks like modelers were generally satisfied with the traditional condition of no zonal flux at eastern walls, and did not bother for a more realistic one. Veronis (1973) was the first to introduce in his two-layer model a semiempirical representation of alongshore thermocline slopes, the ensuing zonal flows feeding meridional currents in a boundary layer. Luyten et al. (1983) used the classical condition in their analytical model of the ventilated thermocline but pointed out the severe problems raised by this choice. As their model also put emphasis on some aspects of the cir-

Corresponding author address: Dr. M. Arhan, Laboratoire de Physique des Oceans, IFREMER/Centre de Brest, B. P. 70, 29280, Plouzané, France. culation in eastern basins, like the so-called shadow zone, it seems to have been the starting point of a period of new interest in the eastern boundary problem. Pedlosky (1983) and Huang (1989) generalized the classical no-zonal-flux condition into a no-net-zonal-flux condition in which surface water having entered a boundary layer is vertically mixed and reinjected in the ocean interior at deeper levels. The mechanism is called "eastern boundary ventilation" and the alongshore density gradients present in the models eliminate some of the singularities associated with the classical condition. More recently, the adjunction of a surface mixed layer to the thermocline models led Williams (1989) and Huang (1990) to another representation of the eastern boundary with now an eastward flow in the southward shoaling mixed layer, the no-zonal-flow condition being kept below. Upwelling and the westward Ekman drift known to prevail in these regions provide a way of balancing the eastward geostrophic flow. Numerical simulations of combined wind and buoyancy-driven circulation (Cox and Bryan 1984; Colin de Verdière 1989) exhibit nongeostrophic baroclinic boundary layers at meridional coasts that support intense vertical velocities due to enhanced lateral mixing. Boundary ventilation may be generated, whose 


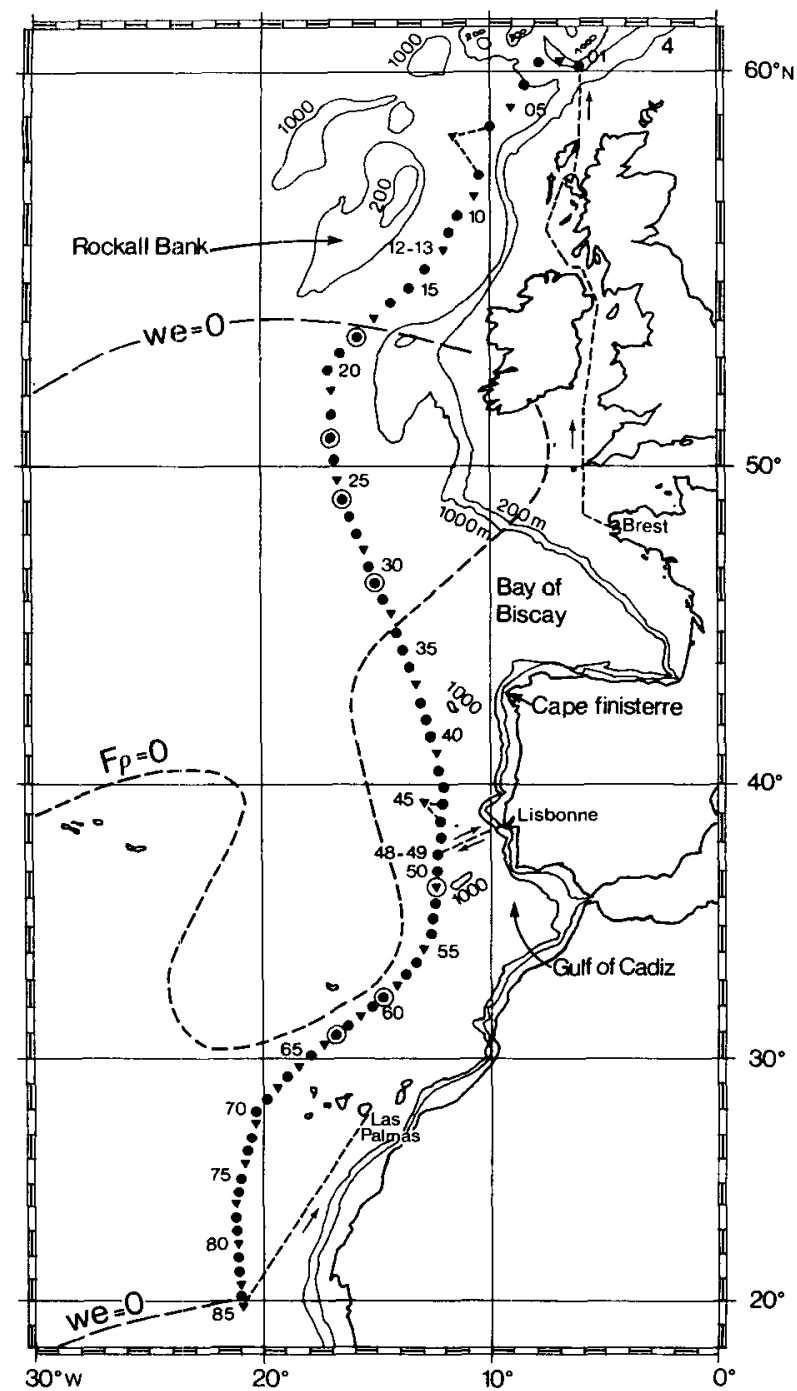

FIG. 1. The Bord-Est hydrographic section with the Leetmaa and Bunker (1978) lines of zero Ekman pumping $\left(w_{e}=0\right)$ and the Schmitt et al. (1989) line of zero average density flux into the ocean $(F \rho$ $=0$ ). The stations marked by an open circle are those where mesoscale structures were observed (section 8 ). Water samples for tritium and helium 3 (not used in this paper) were taken at those stations shown by a triangle.

effect is most intense around and north of the transition between the subtropical and subpolar gyres.

Interest in the eastern boundary of the North Atlantic also stems from the presence there of the source of Mediterranean Water (MW). As this water mass flows out of the Gulf of Cadiz, a part of it is entrained northward in an allongslope current before eventually turning west. How much of the source follows this route, how much directly flows into the ocean interior, and how much is entrapped in westward propagating meddies are questions presently under debate. Provided that a satisfactory North Atlantic advection-diffusion model was available, it should be fed at its eastern limit by a realistic MW source in order to correctly reproduce the spreading of this water mass. Measurements of salinity and other tracers at a line along the coast but west of the boundary layer should be a useful step toward understanding the complexity of the MW source.

These two questions, the determination of the geostrophic boundary condition and that of the MW source function were at the onset of the experimental Bord-Est program, and more specifically of the eastern boundary hydrographic section presented in this paper. Another part of the program, not discussed here, consisted in a more local study west of the Iberian Peninsula, aimed at describing the behavior of the MW in the eastern boundary layer.

The hydrographic section, represented in Fig. 1, spans the latitudinal range $20^{\circ}-60^{\circ} \mathrm{N}$. It is located at an average distance of $200 \mathrm{n}$ mi from the continental slope but ignores the opening of the Bay of Biscay. Also shown in the figure are the lines of zero Ekman pumping from Leetmaa and Bunker (1978), which intersect the section at $53^{\circ} \mathrm{N}$ and its southern end, and that of zero net surface density flux reproduced from Schmitt et al. (1989). South of $53^{\circ} \mathrm{N}$ our section may be considered the eastern limit of the so-called subtropical North Atlantic. North of that latitude it runs approximately along the axis of the Rockall Channel, and ends north of the Wyville-Thompson ridge in the Faroe Bank channel.

The cruise was carried out in the spring from 10 May to 6 June 1988 for two main reasons: the summer was discarded for being the season of maximum upwelling at the Iberian coast, and it was thought useful to sample the northern part of the line shortly after the end of winter, on the ground that the mixed layer water is injected in the permanent thermocline with its late winter characteristics (Stommel 1979).

In this study we analyze the data with the main purpose of estimating the zonal transports across the line and discussing them in terms of water masses. We give special attention to the two topics of the MW distribution and the oceanic ventilation. After a brief presentation of the vertical distribution of selected parameters in section 2, the water mass descriptions in sections 3-5 (for the upper, intermediate, and bottom layers) focus on the $\mathrm{MW}$ and a few other aspects either related to ventilation, like the winter mixed layer, or pertinent to the velocity discussion, like the water mass boundaries and the Antarctic Bottom Water signature. Section 6 presents the density distribution and geostrophic velocities, and section 7 the associated transports. All this refers to the large-scale circulation; however, two types of mesoscale structures were also observed that we thought worth describing in section 8 , on account of their possible roles in the oceanic ventilation and the MW transport. These are surface intensified eddies present in the winter mixed layer north of about $45^{\circ} \mathrm{N}$, and several meddies south of $37^{\circ} \mathrm{N}$. 


\section{The data and vertical sections}

A thorough description of the dataset and its quality may be found in the data report of the Bord-Est 2 cruise (Arhan et al. 1991b). Briefly, 85 CTD-tracer stations were carried out from the $\mathrm{R} / \mathrm{V}$ Jean Charcot at a nominal spacing of $35 \mathrm{n} \mathrm{mi} \mathrm{(Fig.} \mathrm{1).} \mathrm{The} \mathrm{ocean} \mathrm{was}$ generally deeper than $4000 \mathrm{~m}$ along the line, except in the Rockall Channel north of approximately $52^{\circ} \mathrm{N}$. Data were acquired at each station from the surface down to $10-100 \mathrm{~m}$ from the bottom, with water samples at 16 levels for the CTD sensor calibration and the analysis of nitrates and silicates.

Vertical distributions of all measured parameters as a function of pressure are shown in the aforementioned data report, and are not reproduced here. It was thought preferable in this paper to have the water mass analysis rest on the vertical distributions of properties with respect to density. Figure 2 showing the potential density section provides the link between pressure and density, the distributions themselves being displayed on Figs. 3 a-d for potential temperature $(\theta)$, salinity $(S)$, dissolved oxygen $\left(\mathrm{O}_{2}\right)$, and nitrates $(\mathrm{Ni})$.

The properties were computed at 70 potential density levels, 30 of them being $\sigma_{\theta}$ values, the other ones being values of potential density referred to $1000 \mathrm{db}$ and multiples (respectively $\sigma_{1}$ to $\sigma_{5}$ ). To display the distributions, the vertical axes in Figs. 3a-d were first marked with a density index (1-70, with a scale twice larger above 25 , or $\sigma_{\theta}=27.0$ ), this graduation being replaced afterward by the density graduation. Isopycnals and density scale were chosen so as to correctly visualize property gradients at all levels. Enhanced resolution at the upper levels was obtained in this way, with the $\sigma_{\theta}$ isopycnals occupying about a third of the density axis, although they are generally confined to the upper $800 \mathrm{db}$ (Fig. 2). The lower limit in the figures represents the first isopycnal value not reached by the observations.

The nutrients were interpolated at density levels from the sample values. Some smoothing of the original profiles of the CTD-O $\mathrm{O}_{2}$ parameters was necessary to eliminate features of small vertical scales from the plots. This was performed by using a Gaussian filter of standard deviation $15 \mathrm{db}$ on potential temperature and dissolved oxygen, and $30 \mathrm{db}$ on salinity.

\section{Central waters}

Central waters occupy the layer from below the seasonal thermocline to the density $\sigma_{1}=31.8\left(\sigma_{\theta} \approx 27.3\right)$ on Fig. 3. The seasonal thermocline is represented by an upper fringe with northward rising isotherms and nearly vertical isohalines. The isopycnal $\sigma_{1}=31.8$ is found at about $750 \mathrm{db}$ over most of the section, but outcrops near $56^{\circ} \mathrm{N}$ in the Rockall Channel. We describe in turn the transition from the North Atlantic Central Water (NACW) to the South Atlantic Central Water (SACW) and the existence of a winter mixed layer throughout most of the section. As a basis for the description, the $\theta-S$ scatter diagrams are shown in Fig. 4 for three groups of stations corresponding to Rockall Channel (Fig. 4a), the region of NACW (Fig. 4b), and the southernmost region influenced by SACW (Fig. 4c).

\section{a. The NACW-SACW transition}

NACW is characterized in Figs. $3 a$ and $3 b$ by quasihorizontal isotherms and isohalines over most of the above density domain, with the exception of the seasonal thermocline and another region south of about $25^{\circ} \mathrm{N}$ (station 76) where isopleths show an irregular southward slope; this is the area of influence of the less saline SACW.

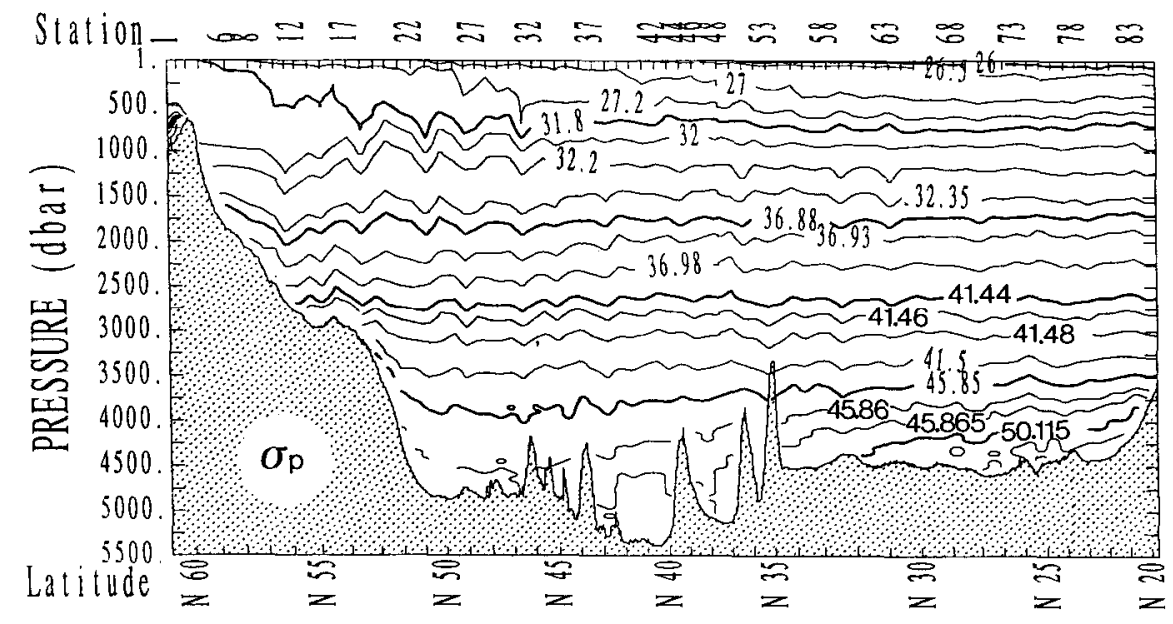

FIG. 2. Vertical distribution of the potential density referred to pressure multiples of $1000 \mathrm{db}$, along the Bord-Est line. Bold isolines mark a change in the reference pressure of the potential densities. Note the varying contour interval. 

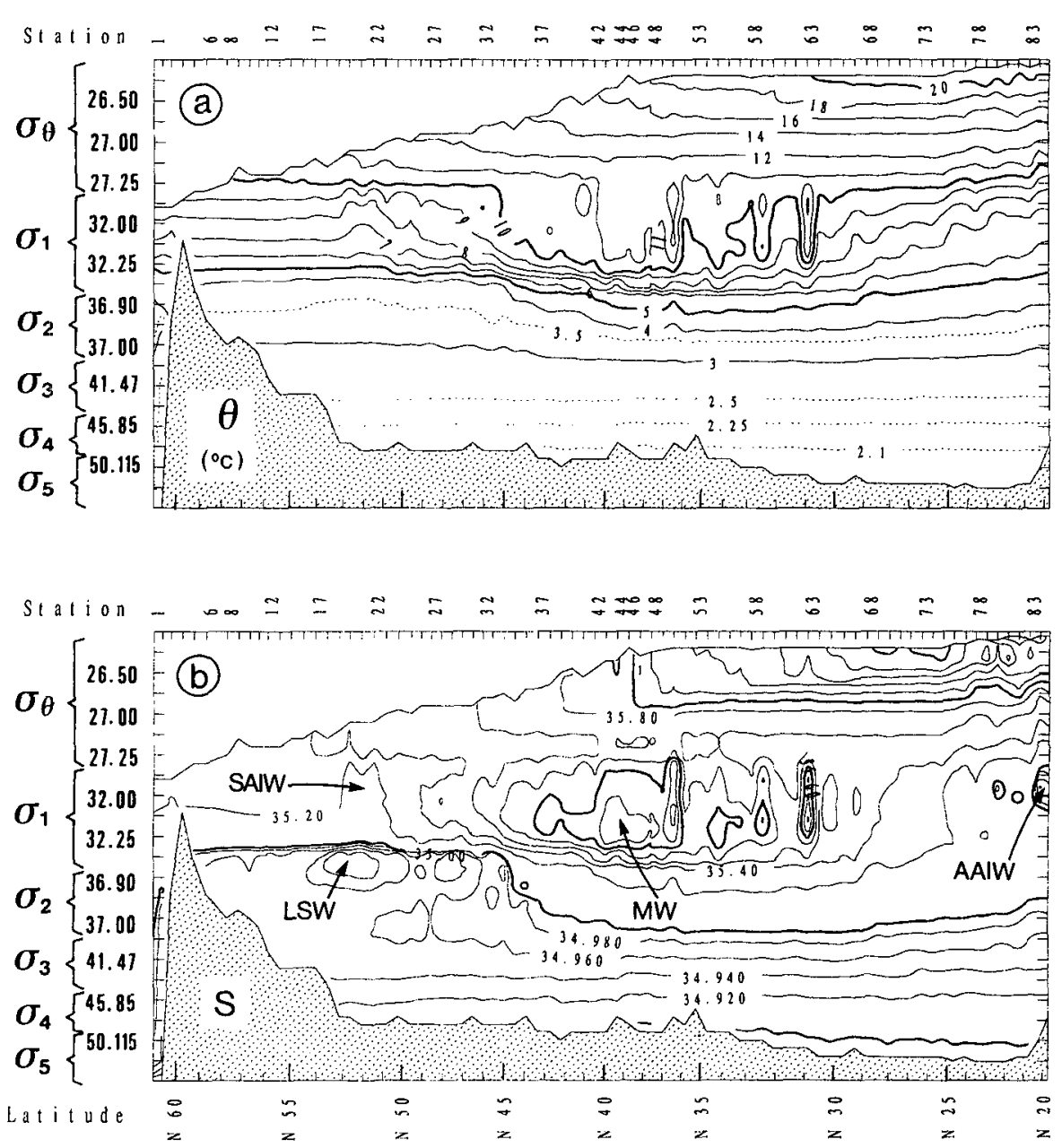

FIG. 3. Vertical distributions (with respect to density) of potential temperature (a), salinity (b), dissolved oxygen (c), and nitrate (d). The vertical parameter is the composite potential density $\sigma_{p}$ referred to pressure multiples of $1000 \mathrm{db}$ (see Fig. 2). The graduation is linear within each subdomain associated with a particular reference pressure, but different from one subdomain to another. Acronyms on the salinity distribution (b) show some of the major water masses: Subarctic Intermediate Water (SAIW), Labrador Sea Water (LSW), Mediterranean Water (MW), and Antarctic Intermediate Water (AAIW).

The Central Waters boundary has been subject to many investigations in the region off West Africa where it is related to upwelling at the coast. It is generally described as a strong meandering thermohaline front near Cap Blanc at latitudes of $20^{\circ}$ to $22^{\circ} \mathrm{N}$, that is, at the very end of our section (Hughes and Barton 1974; Tomczak and Hughes 1980; Barton 1987; Zenk et al. 1991; Fiekas et al. 1992). The front is associated with a convergence at the coast between the Canary Current conveying NACW southward and a northward flow of SACW. The Canary Current leaves the coast at about $22^{\circ} \mathrm{N}$ but the alongslope northward flow continues as an undercurrent to at least $25^{\circ} \mathrm{N}$. This undercurrent is most intense at about $250 \mathrm{~m}$ or densities around 26.8 and extends to depths more than $1000 \mathrm{~m}$ (Mittelstaedt 1983). The NACW $\theta-S$ relationship stands out in Fig. 4b and would be well represented in the range $10^{\circ} \mathrm{C}<\theta<13^{\circ} \mathrm{C}$ by the straight line through $\left(10^{\circ} \mathrm{C}, 35.405 \mathrm{psu}\right)$ and $\left(12^{\circ} \mathrm{C}, 35.65 \mathrm{psu}\right)$ proposed by Harvey (1982) from an analysis of historical data from the northeast Atlantic. The $\theta-S$ relationship for SACW reported on Fig. $4 \mathrm{c}$ is defined following Tomczak and Hughes (1980) by the straight line between the points $\left(10^{\circ} \mathrm{C}, 35.21 \mathrm{psu}\right)$ and $\left(16^{\circ} \mathrm{C}, 35.77 \mathrm{psu}\right)$. It is clear from these plots that what is seen south of $25^{\circ} \mathrm{N}$ on our section is not pure SACW, but a mixture of SACW and NACW. The front itself was not observed, being probably located south of $20^{\circ} \mathrm{N}$ at the time of the cruise.

The influence of SACW stands out even more clearly on the dissolved oxygen and nitrates distributions (Fig. $3 c, d)$, which both show a marked front in the density range $\sigma_{\theta} \leqslant 27.25$ at stations $75-77$. South of this limit the stations most influenced $(78-80$ and 84,85$)$ have 

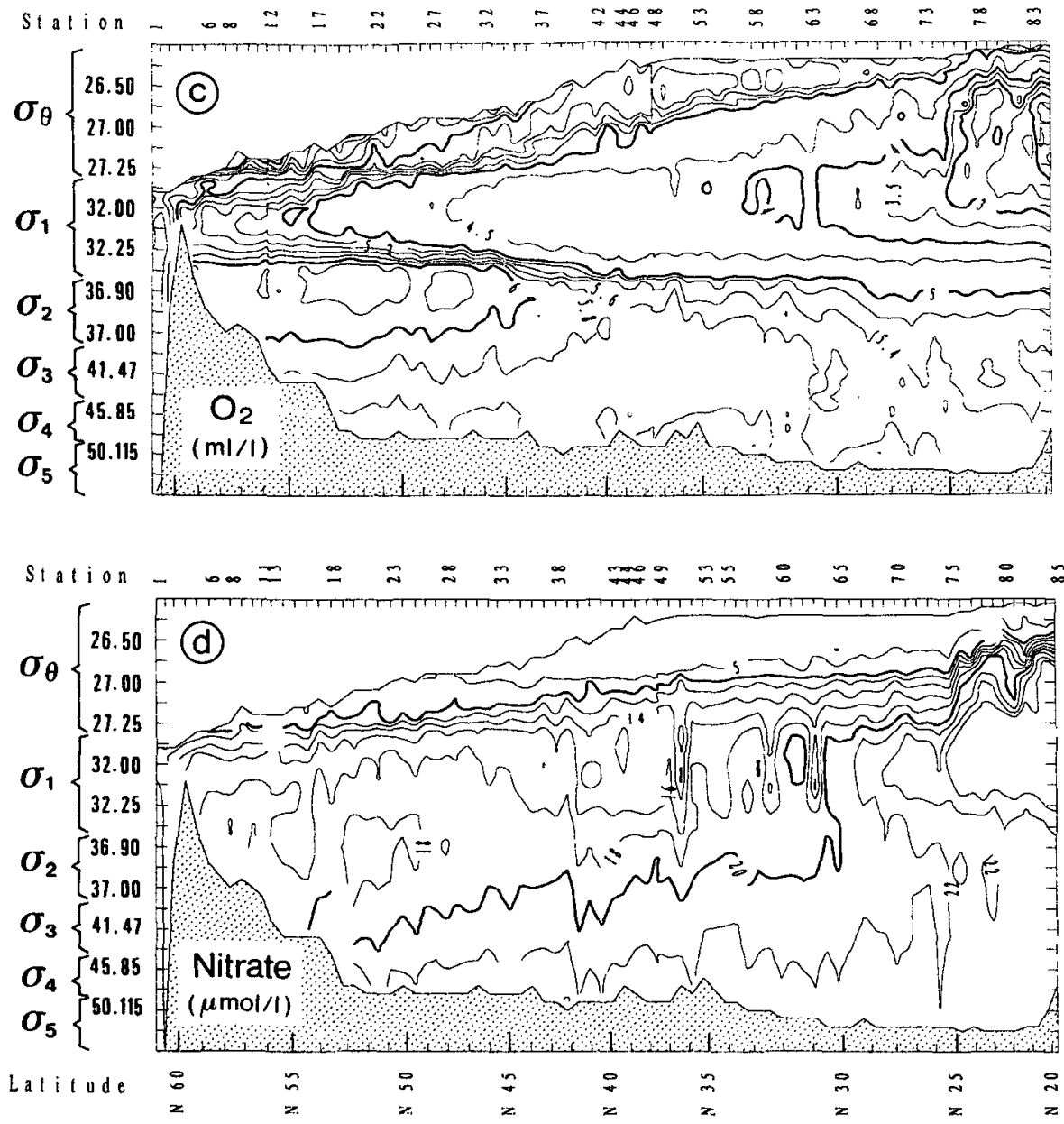

FIG. 3. (Continued)
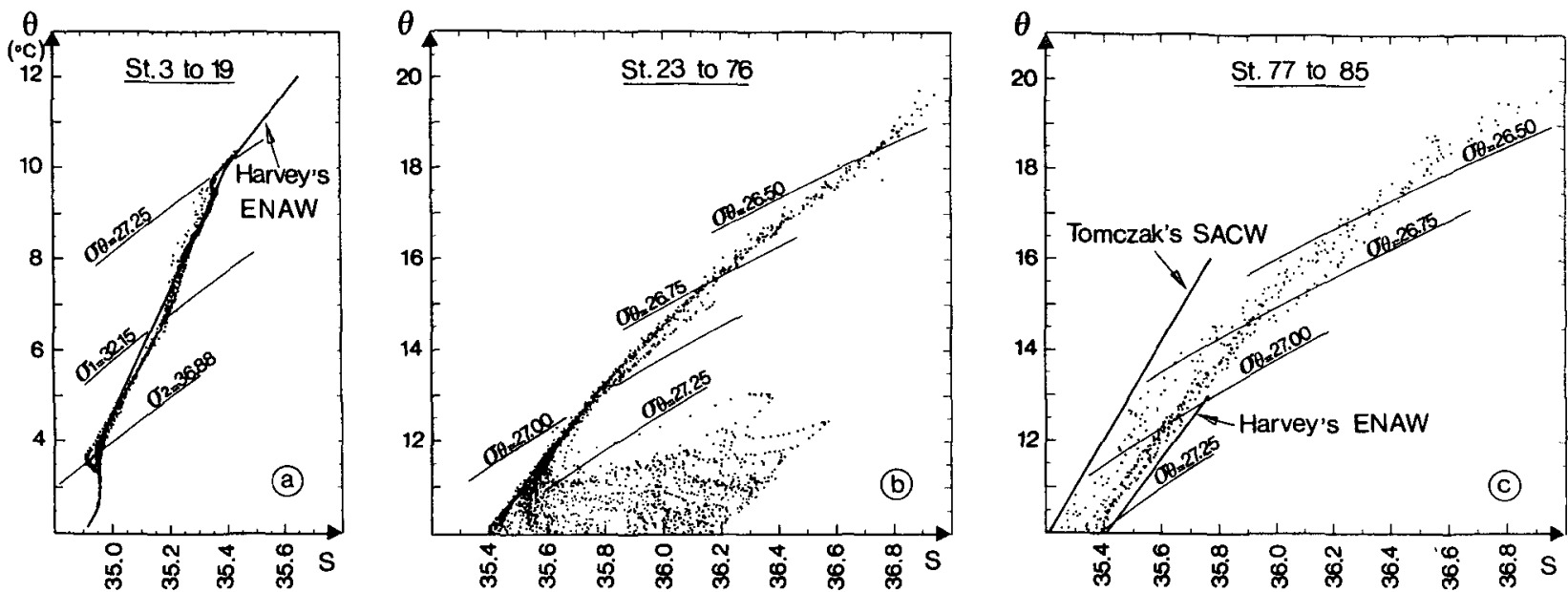

FIG. 4. $\theta-S$ diagrams: (a) in Rockall Channel; Harvey's (1982) curve for eastern North Atlantic Water (ENAW) is superimposed. (b) At latitudes $25^{\circ}-51^{\circ} \mathrm{N}$ dominated by NACW influence. (c) South of $25^{\circ} \mathrm{N}$ where SACW is present; Tomczak and Hughes's (1980) line for the SACW, and Harvey's (1982) line of the ENAW are superimposed. 

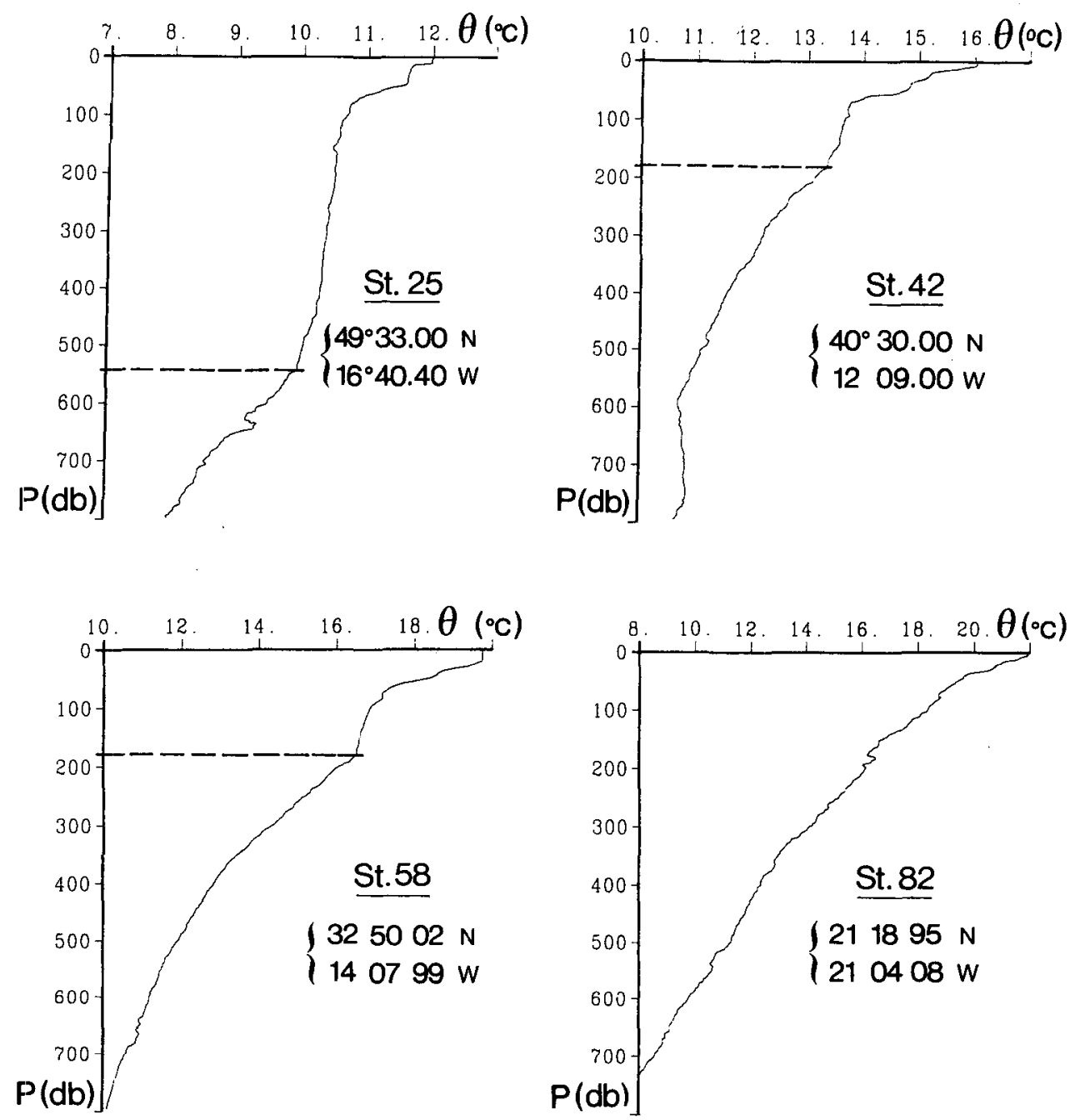

Fig. 5. Selected profiles of potential temperature for the determination of the winter mixed layer depth, where it existed. The existence of a mixed layer was determined visually and its depth using a $0.5^{\circ} \mathrm{C}$ change criterion. Station 82 shows no trace of a winter mixed layer.

a well-defined oxygen minimum (down to $1.1 \mathrm{ml} \mathrm{l}^{-1}$ at station 85) located at about $\sigma_{\theta}=26.8$, another indication that this water has been transported by the alongshore northward undercurrent of similar density. Our data therefore suggest the transition from SACW to NACW to occur in two steps. A first front near $20^{\circ} \mathrm{N}$, which unfortunately was not sampled here, marks the northern limit of SACW. A second one, most apparent on the oxygen distribution, marks the southern limit of NACW around $25^{\circ} \mathrm{N}$. In between is found a mixture of both water masses.

\section{b. The winter mixed layer}

Intense winter convection is known to occur in the region crossed by the northern half of the Bord-Est section. A map of the depth of the mixed layer in March in Robinson et al. (1979) shows values as high as 900 $\mathrm{m}$ in Rockall Channel and well above $500 \mathrm{~m}$ north of the latitude of Cape Finisterre. As the Bord-Est 2 cruise took place in May and early June, the winter mixed layer, where it existed, was already capped by a beginning of seasonal thermocline but could nevertheless be observed, and its depth estimated.

Inspection of the temperature profiles (Fig. 5) revealed that a mixed layer was present at nearly all stations containing NACW, with the exception of a few ones offshore from the Gulf of Cadiz. On the contrary, the stations to the south of $25^{\circ} \mathrm{N}$ containing a percentage of SACW showed no trace of a mixed layer. The mean depths of the mixed layer have been reported on the section of potential density in the upper 1000 $\mathrm{db}$ on Fig. 6. To eliminate the numerous mesoscale features visible on Fig. 2, we used a horizontally smoothed potential density, and the winter mixed layer domain thus defined compares well with that from the 


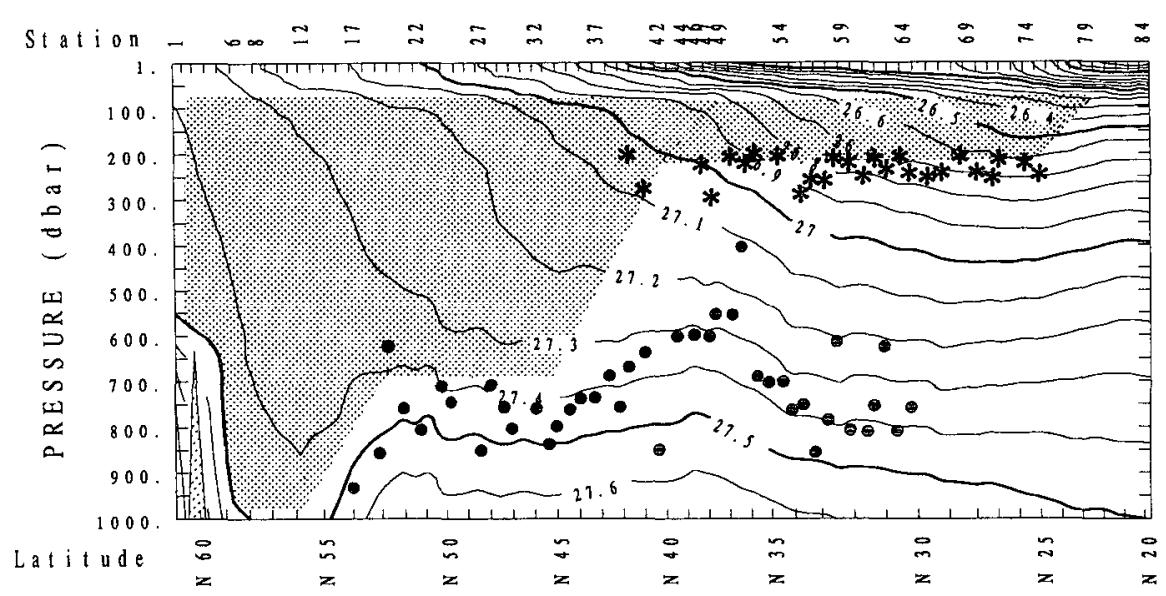

FIG. 6. Vertical distribution of laterally smoothed potential density in the upper $1000 \mathrm{db}$. Smoothing was performed as a running mean over seven adjacent stations. Shading accounts for the winter mixed layer. Dots and stars stand for the main and secondary pycnocline, respectively (see section 6a).

map of Robinson et al. (1979) along the cruise track. The mixed layer is deepest in the Rockall Channel where it approaches $1000 \mathrm{~m}$. It has the approximate depth $700 \mathrm{~m}$ from about $53^{\circ} \mathrm{N}$ to $45^{\circ} \mathrm{N}$, then reduces to $200 \mathrm{~m}$ southward in three degrees of latitude. It keeps the latter value up to the southern limit of the NACW. Its temperature increases and density decreases southward from values of about $9^{\circ} \mathrm{C}$ and $\sigma_{\theta}=27.3$ in the Rockall Channel to $16^{\circ}-18^{\circ} \mathrm{C}$ and $\sigma_{\theta}=26.6$ at $25^{\circ}$ $30^{\circ} \mathrm{N}$. The mixed layer water in the latter region is the Madeira mode water studied by Siedler et al. (1987). This description characterizes the late winter situation and should not, of course, be extended to other seasons. As an example, Siedler et al. (1987) showed the Madeira mode water to almost completely disappear in the course of the year.

The water occupying the winter mixed layer of Rockall Channel (hereafter the Rockall Channel mode water) deserves special notice as it is slightly different from the NACW. Coming back to Fig. $4 \mathrm{a}$, it is visible as a gathering of points in the temperature range $8^{\circ}-$ $10^{\circ} \mathrm{C}$. Also shown is the curve proposed by Harvey (1982) as defining the so-called Eastern North Atlantic Water (ENAW). This curve is here simplified into two straight line segments, the first one for temperatures greater than $10^{\circ} \mathrm{C}$ having already been defined above, the lower one being an extension with a slightly different slope from the point $\left(10^{\circ} \mathrm{C}, 35.405\right.$ psu $)$ to $\left(4^{\circ} \mathrm{C}\right.$, $34.96 \mathrm{psu}$ ). The upper segment was shown to provide a good representation of the $\theta-S$ relationship of the NACW along the eastern boundary. Relevance of the lower part to observations in the Rockall Channel has already been mentioned by Ellett et al. (1986) in their study of the hydrography of this area. This is confirmed here, as most points in Fig. 4a fall upon it, particularly in the mode water temperature range.
Isopycnals for densities higher than $\sigma_{1}=32.0$ in the Rockall Channel are bowl shaped in Fig. 2, their deepest point being at our station 11 at about $56^{\circ} \mathrm{N}$. This longitudinal view along the axis of the channel matches the many published transverse sections (e.g., Ellett and Martin 1973; the $58^{\circ} \mathrm{N}$ IGY transect), which all also exhibit bowl-shaped isotherms and isohalines. Assuming that a level of no motion exists at depth, this leads to a basic anticyclonic circulation of the Rockall Channel mode water, as will be seen below.

\section{Intermediate waters}

We describe in this section the waters found below the central waters south of Rockall Channel, in the density range $27.3 \leqslant \sigma_{\theta, 3} \leqslant 41.5$ corresponding approximately to pressures between 750 and $3500 \mathrm{db}$. The setting of water masses in this domain, is well defined, with the MW occupying the central position, bounded to the north by Labrador Sea Water (LSW) and Sub-Arctic Intermediate Water (SAIW), and to the south by Antarctic Intermediate Water (AAIW). This arrangement is illustrated in Fig. 7 showing the $N i-S$ diagram along the isopycnal $\sigma_{1}=32.15$. Although nitrate is admittedly not a conservative tracer at the depth of this isopycnal $(\approx 1000 \mathrm{~m})$, the three water masses present (SAIW, MW, and AAIW) exhibit welldefined and differing signatures, so that the degree of influence of each of them at a given station may be inferred from the diagram. Mixing lines between MW and both SAIW and AAIW do stand out. A similar pattern was observed at a higher density with LSW replacing SAIW (not shown).

\section{a. Intermediate waters other than the Mediterranean Water}

The LSW is best observed on the salinity section (Fig. $3 \mathrm{~b}$ ) as a minimum in the density range 32.25 


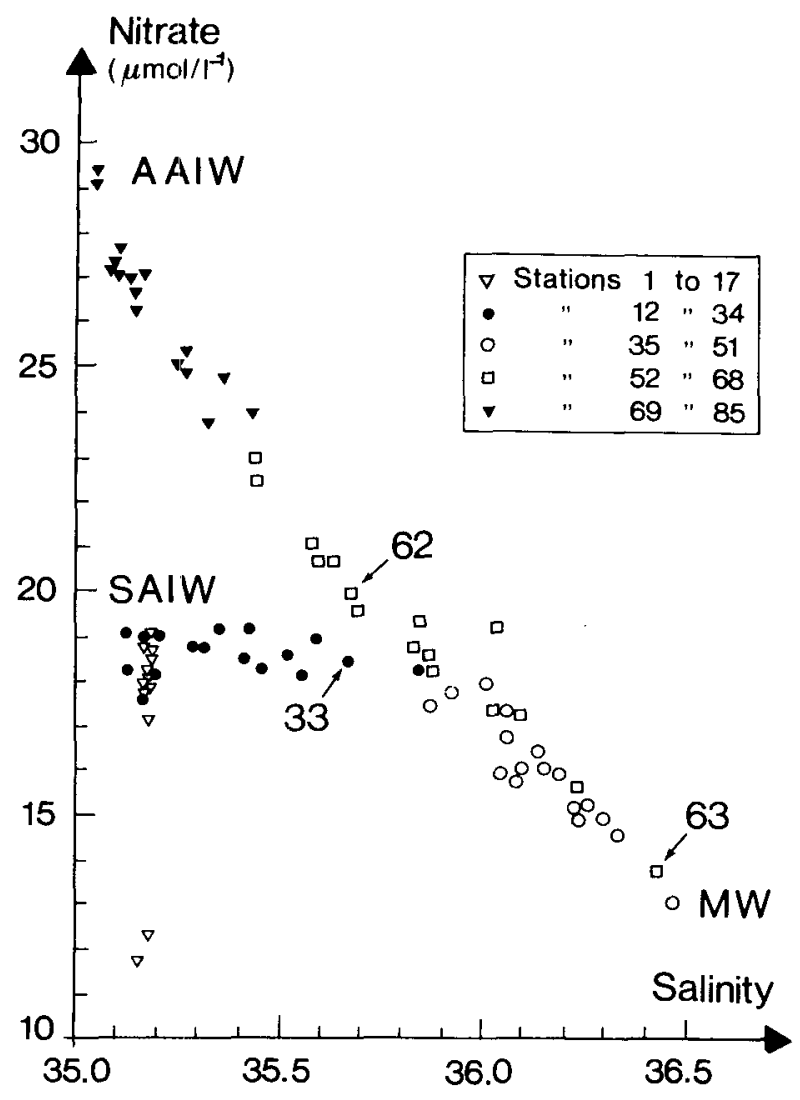

FIG. 7. Nitrate-salinity diagram along isopycnal $\sigma_{1}=32.15$. Stations 33 and 62 have been spotted to show the limit of influence of the SAIW and the AAIW. Station 63, also marked, sampled a meddy.

$<\sigma_{1,2}<36.98$, north of $45^{\circ} \mathrm{N}$. At this latitude the quasi coincidence of the vertical isohalines 34.98 and $35.00 \mathrm{psu}$ is indicative of an abrupt transition to the more saline deep MW to the south. A southward density gradient seems to accompany the thermohaline front, as may be seen from the rising of the isopycnal 36.98 from $\sim 2450 \mathrm{db}$ at $47^{\circ} \mathrm{N}$ to $\sim 2300 \mathrm{db}$ at $43^{\circ} \mathrm{N}$. The LSW spreads over the bottom of Rockall Channel at densities greater than $\sigma_{1}=32.25$ (Fig. 3b), but its influence is most pronounced south of the channel between $50^{\circ}$ and $54^{\circ} \mathrm{N}$ as seen from the closed isohalines 34.92 and 34.94 psu. These contours signal out a tongue of LSW flowing zonally eastward along $\sim 52^{\circ} \mathrm{N}$ and described by Pingree (1973) and Talley and McCartney (1982). We have confirmation here that this tongue reaches the eastern boundary of the basin. It is expected to impinge onto the continental slope west of Porcupine Plateau and be deflected southward toward the Bay of Biscay and northward into Rockall Channel.

Above the tongue of LSW at stations 20 to 23 lies a relatively fresh and cold water (Fig. 3a,b) recognizable through its $\theta-S$ characteristics as SAIW. A vertical minimum in salinity exists at these stations at densities
$27.3 \leqslant \sigma_{\theta, 1} \leqslant 32.25$, which is replaced, south of $50^{\circ} \mathrm{N}$, by the maximum characteristic of MW. The SAIW originates at about the same latitudes in the western basin where it is found at the surface north of the polar front (Bubnov 1968). A zonal hydrographic transect along $53^{\circ} 30^{\prime} \mathrm{N}$ carried out by the R/V Erika Dan during winter 1962 illustrates its eastward spreading (Harvey 1982): SAIW occupies the upper $500 \mathrm{~m}$ of ocean west of $22^{\circ} \mathrm{W}$, the longitude where the polar front crosses the Erika Dan line. East of that point a subducted and mixed form of it extends to approximately $18^{\circ} \mathrm{W}$ beneath a layer of NACW $300 \mathrm{~m}$ thick. Stommel et al. (1977) observed a patch of it between $18^{\circ}$ and $19^{\circ} \mathrm{W}$ at the same latitude. In a study of the long-term hydrographic variations at the ocean weather station Juliett $\left(52^{\circ} 30^{\prime} \mathrm{N}, 20^{\circ} \mathrm{W}\right)$, Ellett (1980) found an intermediate salinity minimum lower than 35.2 in about $80 \%$ of the profiles from the 1964-1975 period. It cannot be stated whether the SAIW signal seen during Bord-Est at $17^{\circ} \mathrm{W}$ (Fig. $3 \mathrm{~b}$ ) is a cross section of a tongue similar to that of the LSW beneath, or of an isolated eddy, but this and the previous observations suggest that the presence of SAIW up to the approaches of the continental slope at latitudes $50^{\circ}$ to $54^{\circ} \mathrm{N}$ and densities $27.3 \leqslant \sigma_{\theta, 1} \leqslant 32.25$, is the normal state.

In the southern part of the section (Fig. 3b) the Antarctic Intermediate Water (AAIW) is detected from its fresh anomaly centered at about $\sigma_{1}=32.0$. This anomaly decreases northward but the $S-N i$ diagram of Fig. 7 , where station 62 at $31^{\circ} \mathrm{N}$ has been spotted, shows that AAIW is still present though strongly mixed north of the Canary Islands. This water mass thus extends its influence well beyond that of the SACW, which was seen to be limited at $25^{\circ} \mathrm{N}$. As both AAIW and SACW are thought to be transported northward by the alongslope undercurrent, this is an indication that the deep part of this current, though less intense than the shallower part, extends farther north and flows east of the Canary Islands. The transition between AAIW and MW, though occurring over a wide latitudinal range, is very irregular along the Bord-Est line, due to the presence of several meddies. This again may be seen in Fig. 7 by comparing the salinity and nitrate values on $\sigma_{1}=32.15$ at the neighboring stations 62 and 63 .

\section{b. The Mediterranean Water}

The Bord-Est line provides a cross section of the large-scale MW plume, best visible from the distributions of potential temperature and salinity (Figs. 3a,b). The salinity anomaly is most intense in the density range $27.3 \leqslant \sigma_{\theta, 1} \leqslant 32.35(700 \leqslant p \leqslant 1500 \mathrm{db})$ but is detected as deep as $3000 \mathrm{db}$ on $\sigma_{1} \approx 41.47$. Doublediffusive mixing is often invoked to explain the influence of the MW at such depths. The latitudinal distribution of MW shows some irregularities particularly in the southern half of the plume where our line happened to intersect several meddies. Three of them stand 
out at stations 51,59 , and 63 , and we may have crossed the edge of a fourth one at station 55. Further description of these structures is deferred to section 8 . The MW is also characterized between $36^{\circ}$ and $42^{\circ} \mathrm{N}$ and in the meddies by nitrate values lower than $16 \mu \mathrm{Ml}^{-1}$ as compared to background concentrations well above $18 \mu \mathrm{Ml}^{-1}$ at similar depths. The role of nitrate in tracing the MW is illustrated in Fig. 7 and was recently pointed out by Minas et al. (1991).

The sections of potential temperature, salinity, and nitrate all suggest the main $\mathrm{MW}$ inflow into the ocean interior to take place between $36^{\circ} \mathrm{N}$ and $41^{\circ}-42^{\circ} \mathrm{N}$, that is, between the Gorringe and Galicia Banks. This is consistent with Madelain's (1967) and Zenk and Armi's (1990) flow patterns along the Iberian continental slope. The latter authors insist on most of the MW leaving the Gulf of Cadiz through the "Gateway" between Cape St. Vincent and the Gorringe Bank. They also point out the existence of two distinct cores in the vertical, the lower one subject to meandering and spreading westward just north of the gateway, and the upper one proceeding northward along the continental slope.

To quantify the presence of MW along the section a salinity anomaly $\Delta S$ was computed as the difference along isopycnals between the real and a standard $\theta-S$ curve. The latter was determined from the global BordEst $\theta-S$ scatter diagram. It is identical to Harvey's (1982) NEAW relationship for $\theta \geqslant 10^{\circ} \mathrm{C}$, with an extension toward lower potential temperatures to the point $\left(2.6^{\circ} \mathrm{C}, 34.950 \mathrm{psu}\right)$. The positive $\Delta S$ values indicative of MW have been integrated vertically to provide an estimate of the "Mediterranean salt" content at each station. Figure 8a showing the latitudinal distribution of this quantity confirms the MW content to be maximum between $36^{\circ}$ and $41^{\circ} \mathrm{N}$. In the vertical, the relative contributions of the different density layers vary with latitude: Figs. $8 \mathrm{~b}$,c reveal a northward decrease of the pressure and density where $\Delta S$ is maximum. In the region $36^{\circ}-41^{\circ} \mathrm{N}$ where $\Delta S$ is highest, these parameters show values of $p=1200 \mathrm{db}$ and $\sigma_{1}$ $=32.23$ close to those quoted by Zenk and Armi (1990) for the lower MW core. North of $41^{\circ} \mathrm{N}$ the values drop to $p=1000 \mathrm{db}$ and $\sigma_{1}=32.12$, a behavior which could be related to the presence of underlying LSW north of $44^{\circ} \mathrm{N}$. South of about $30^{\circ} \mathrm{N}$, on the other hand, the overlying intrusion of fresh AAIW is the likely reason for a deepening of the maximum of $\Delta S$ to more than $1300 \mathrm{db}$.

Figure $8 \mathrm{a}$ shows the MW content to vanish at about $51^{\circ} \mathrm{N}$ along our section. The tongue of LSW between $50^{\circ}$ and $54^{\circ} \mathrm{N}$, and the SAIW above it, thus appear as a barrier to the northward progression of MW. Yet the presence of some MW in Rockall Channel is generally acknowledged and is indeed apparent as a weak inflexion point at $\sigma_{1}=32.15$ on the $\theta-S$ curve of Fig. 4a. A slight amount of it is also visible north of $\sim 53^{\circ} \mathrm{N}$ on Fig. 8a. As northward transportation of MW into
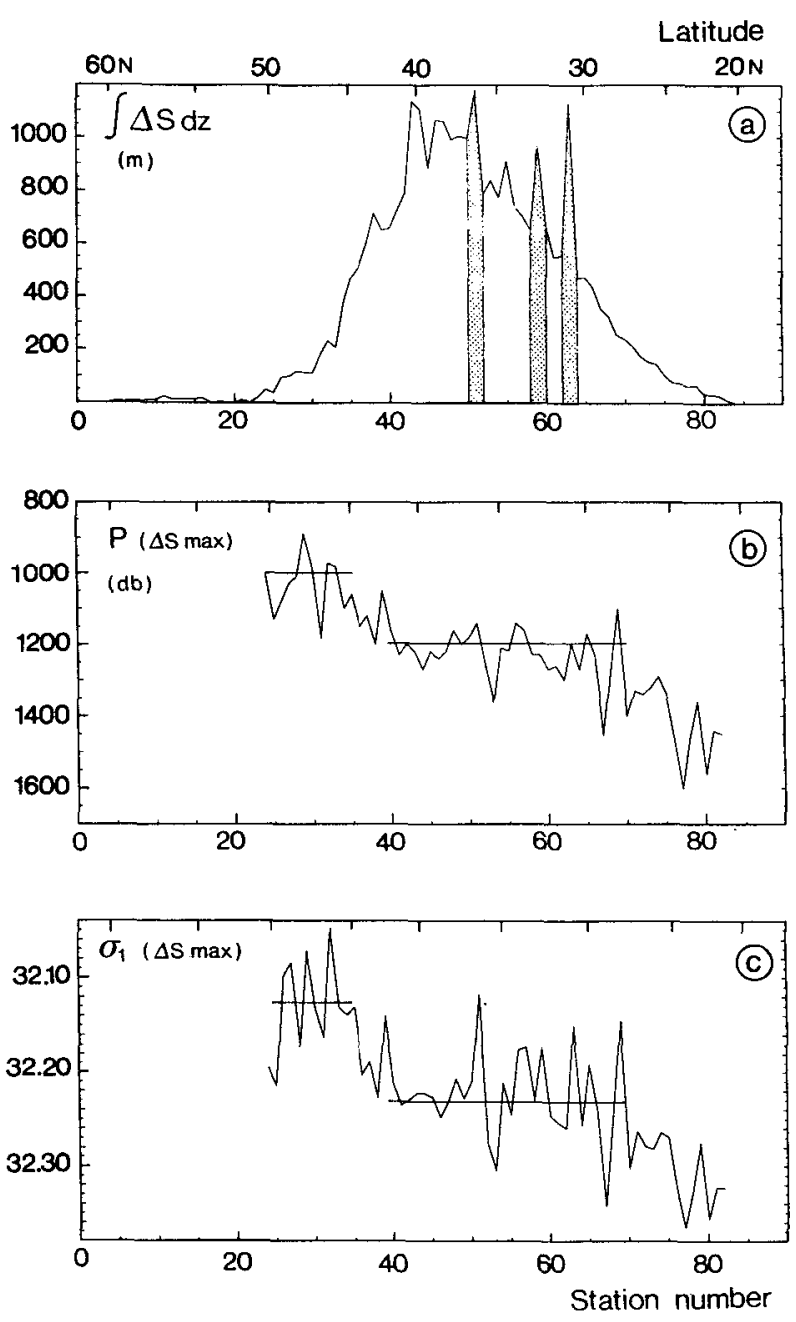

FIG. 8. Latitudinal distribution of (a) the vertical integral of the MW salinity anomaly, with the meddies contribution shaded; (b) the pressure of maximum MW salinity anomaly; and (c) the density $\left(\sigma_{1}\right)$ of maximum MW salinity anomaly.

Rockall Channel does not seem to occur in the ocean interior, it is most likely to be caused by the northward slope current known to exist at these latitudes (Huthnance 1986). This is confirmed by the presence of a limited amount of MW against the continental slope between 800 and $1200 \mathrm{~m}$ on the Erika Dan section along $53^{\circ} 30^{\prime} \mathrm{N}$ shown by Harvey (1982).

\section{The bottom water}

The all-pervading influence of Antarctic Bottom Water (AABW) at the deepest levels of the eastern North Atlantic is a well-known feature of this basin. The inflow occurs at $11^{\circ} \mathrm{N}$ through the Vema Fracture Zone at a rate estimated to a little more than $2 \times 10^{6}$ $\mathrm{m}^{3} \mathrm{~s}^{-1}$ (for $\theta<2{ }^{\circ} \mathrm{C}$ ) by McCartney et al. (1991). The subsequent northward spreading of this water is naturally influenced by the topography, whose main fea- 
tures are reported on the map of Fig. 9. Saunders (1987), McCartney (1992), and McCartney et al. (1991) have described the circulation of diluted AABW in the northeast Atlantic, and its interaction with the various topographic elements. The Bord-Est section provides a view of the northward changes of the bottom water properties as it flows through the successive abyssal plains of the northeastern basin. These changes are best observed on the vertical distributions of potential temperature, salinity, silicate (Fig. 10 for $p$ $>3000 \mathrm{db}$ ), and potential density versus pressure (Fig. 2 ). The potential temperatures show a general northward increase (Fig. 10a) with bottom values lower than $2{ }^{\circ} \mathrm{C}$ at only a few stations south of $27^{\circ} \mathrm{N}$. The salinity (Fig. 10b) and density (Fig. 2) show similar slopes of their near-bottom isopleths. Assuming a middepth reference level (as will be done below) the associated meridional density gradients lead through the geostrophic relation to a bottom intensified eastward flow in the region $20^{\circ}$ to $35^{\circ} \mathrm{N}$. Near-bottom gradients of the same sign leading to a similar flow pattern were observed on another meridional section located some $5^{\circ}$ farther west shown by McCartney et al. (1991).

Although the isopycnal slope is, on the average, welldefined in the latitudinal range $20^{\circ}-35^{\circ} \mathrm{N}$, it shows some irregularities and sign reversals that could be indicative of westward return flows at certain places. Irregularities in the topography of the continental rise, such as those associated with the Canary Islands, may cause these variations. The Seine Abyssal Plain and

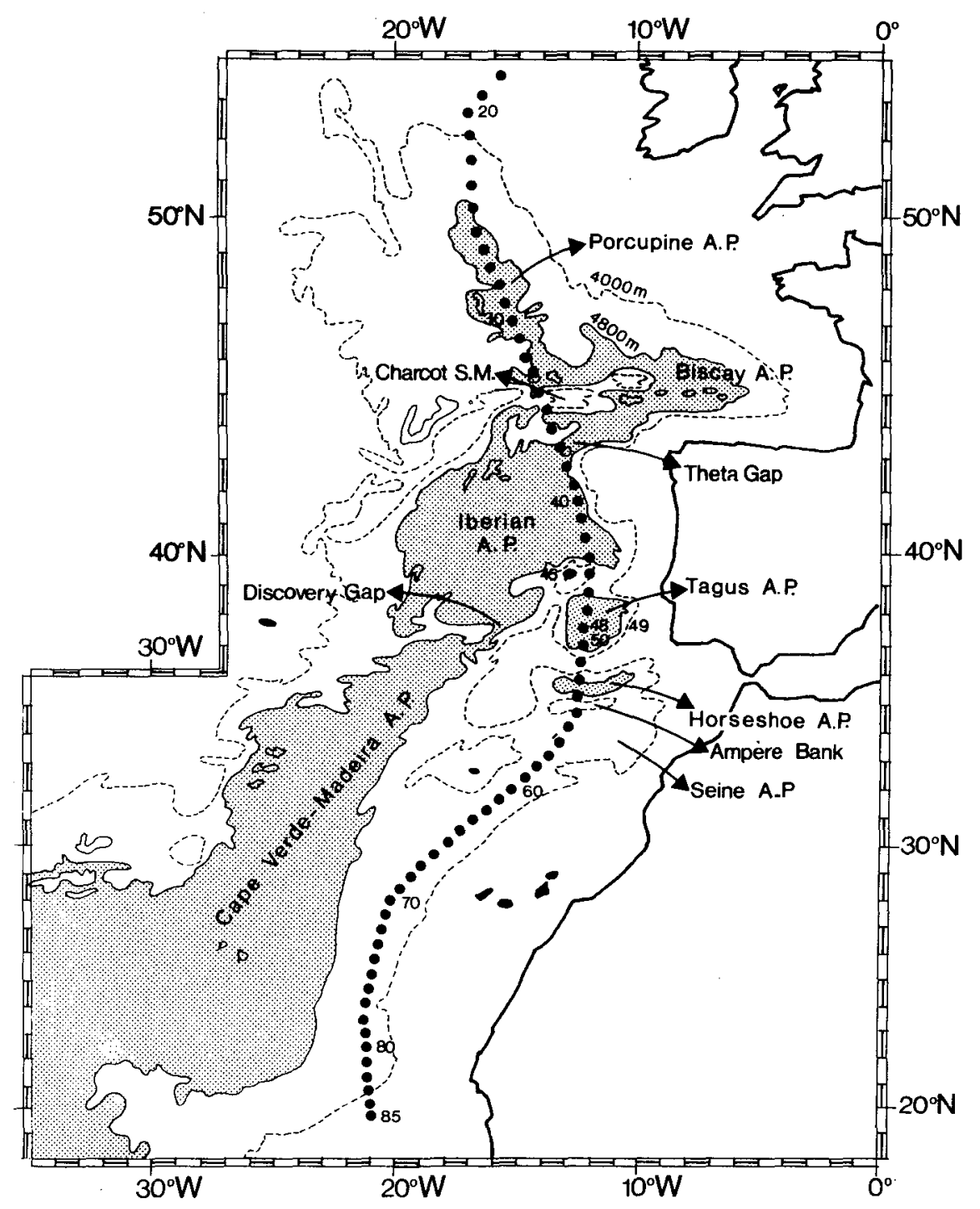

FIG. 9. Main topographic features influencing the spreading of the AABW in the Bord-Est region. Regions deeper than $\mathbf{4 8 0 0} \mathrm{m}$ are shaded. Here, A.P. and S.M. stand for abyssal plain and seamounts, respectively. 


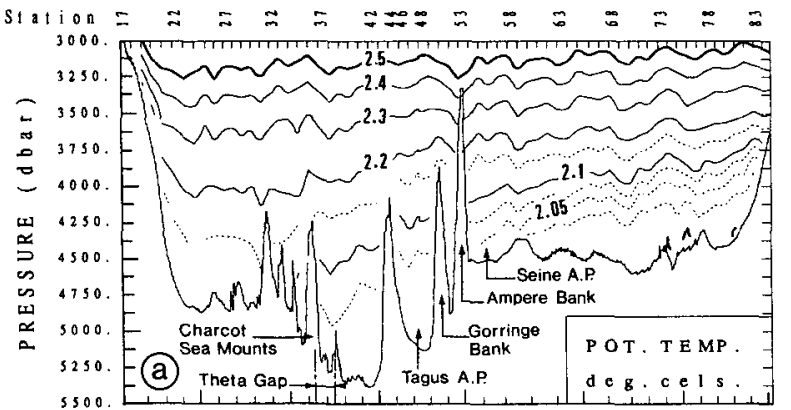

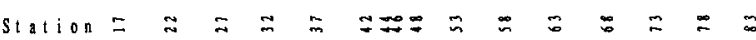
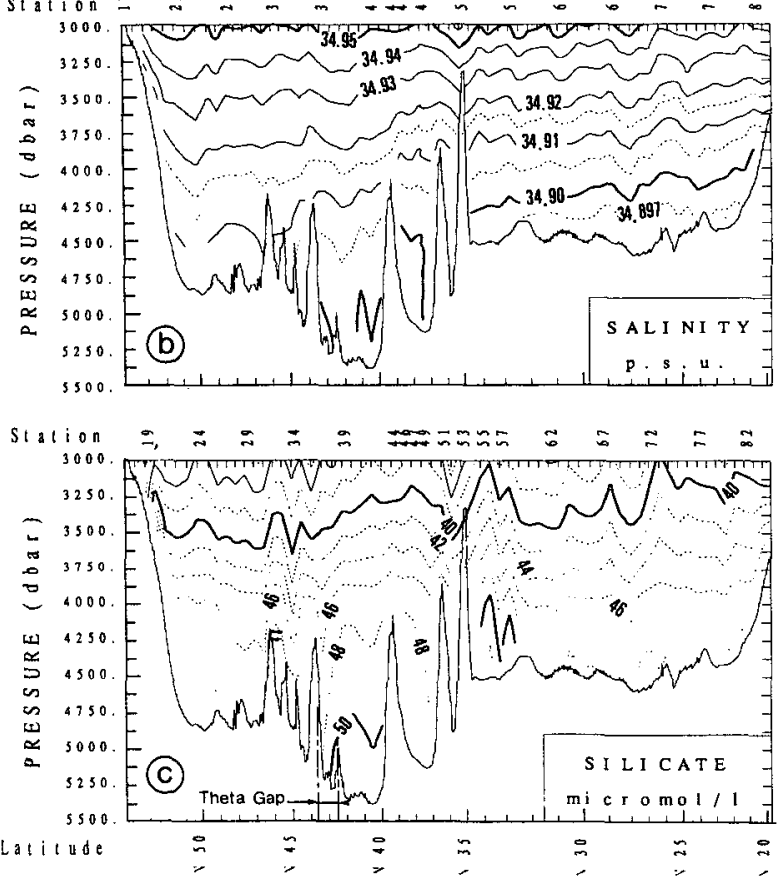

FIG. 10. Vertical distributions (below $3000 \mathrm{db}$ ) of potential temperature (a), salinity (b), and silicate (c).

the Horseshoe Abyssal Plain north of it are separated by Ampere Bank but communicate through two sills of depth $\sim 4200 \mathrm{~m}$. Isotherms, isohalines, and isopycnals above $4200 \mathrm{db}$ all show reversed slopes on either sides of Ampere Bank, suggesting a deep cyclonic circulation around it. In the Horseshoe Abyssal Plain itself the bottom water was found extremely homogeneous in the vertical, with, at station 52 , a quasi-constant potential density $\sigma_{4} \approx 45.863$ from $4200 \mathrm{db}$ to the deepest level $4800 \mathrm{db}$. This homogeneity most probably results from this abyssal plain being closed, and the bottom water not renewed, at these depths. A similar reason could explain the vertical homogeneity below $\approx 4600 \mathrm{db}$ at all stations in the Tagus Abyssal Plain between $37^{\circ} \mathrm{N}$ and $39^{\circ} \mathrm{N}$.

North of $40^{\circ} \mathrm{N}$ our section runs along the eastern boundary of the Iberian Abyssal Plain. The bottom water enters the Iberian basin through the Discovery
Gap, a deep channel visible at about $37^{\circ} \mathrm{N}-16^{\circ} \mathrm{W}$ on the chart of Fig. 9 (Saunders 1987), and leaves it in the north through the Theta Gap, the only deep passage $(>5000 \mathrm{~m}$ ) to the Biscay Abyssal Plain. The Iberian basin is otherwise closed below $\approx 4300 \mathrm{~m}$. The general northward descent of the isopleths observed in the Cape Verde-Madeira basin is accentuated north of the Gorringe Bank, and continues to about $47^{\circ} \mathrm{N}$ where a slope reversal occurs. The increased mean downward slope reflects the northeastward flow of bottom water into the Biscay Abyssal Plain south of the Charcot seamounts. North of this topographic barrier, the slope reversal is to be associated with a westward flow in the Porcupine Abyssal Plain. The slopes of isopleths steepen against the continental rise at the entrance of the Rockall Channel, revealing the existence there of a deep westward boundary current. This feature which stands out at $51^{\circ}-52^{\circ} \mathrm{N}$ along the Bord-Est line was already observed at $\sim 49^{\circ} \mathrm{N}$ against the Goban Spur continental slope on a hydrographic transect from C.S.S. Hudson (Hendry 1989), and farther west at $20^{\circ} \mathrm{W}$ (McCartney 1992). The westward bottom flow in the Porcupine Abyssal Plain also agrees with the set of mean flow vectors from direct measurements in this basin, reported by Dickson, et al. (1985).

On the whole, the bottom water circulation pattern north of $\sim 40^{\circ} \mathrm{N}$ is that of a cyclonic flow around the massif constituted by the Charcot Seamounts and the Biscay Seamounts northeast of them. The mere presence of this topographic obstacle, and the necessity for the water to pass round it may explain the cyclonic circulation. Cyclonic flows are also generally associated with horizontal convergence through potential vorticity conservation. As the North Atlantic eastern basin is closed in the north, horizontal convergence naturally prevails within the bottom water at its northern end, providing an alternative explanation for the cyclonic flow. Horizontal convergence should be associated with vertical mixing and upward velocities. Vertical gradients of potential temperature and salinity are indeed clearly weaker in the northern half of the section than in the southern half (Figs. 10a,b).

\section{Density and geostrophic velocities}

\section{a. Density}

We now compare the real density distribution along the Bord-Est line (Figs. 2 and 6) with the simplified schemes used at the eastern boundary of thermocline models. The domain north of about $52^{\circ} \mathrm{N}$ should probably be considered apart in this discussion, as the circulation and ensuing isopycnal slopes there most certainly reflect a strong topographic influence in the quasi-meridional Rockall Channel. South of this latitude, reality (Fig. 6) is quite different from a no-zonalflux representation. Most isopycnals show an overall northward rise. As an example, $\sigma_{\theta}=27.2$, which is more than $600 \mathrm{db}$ deep at $30^{\circ} \mathrm{N}$, meets the base of the 

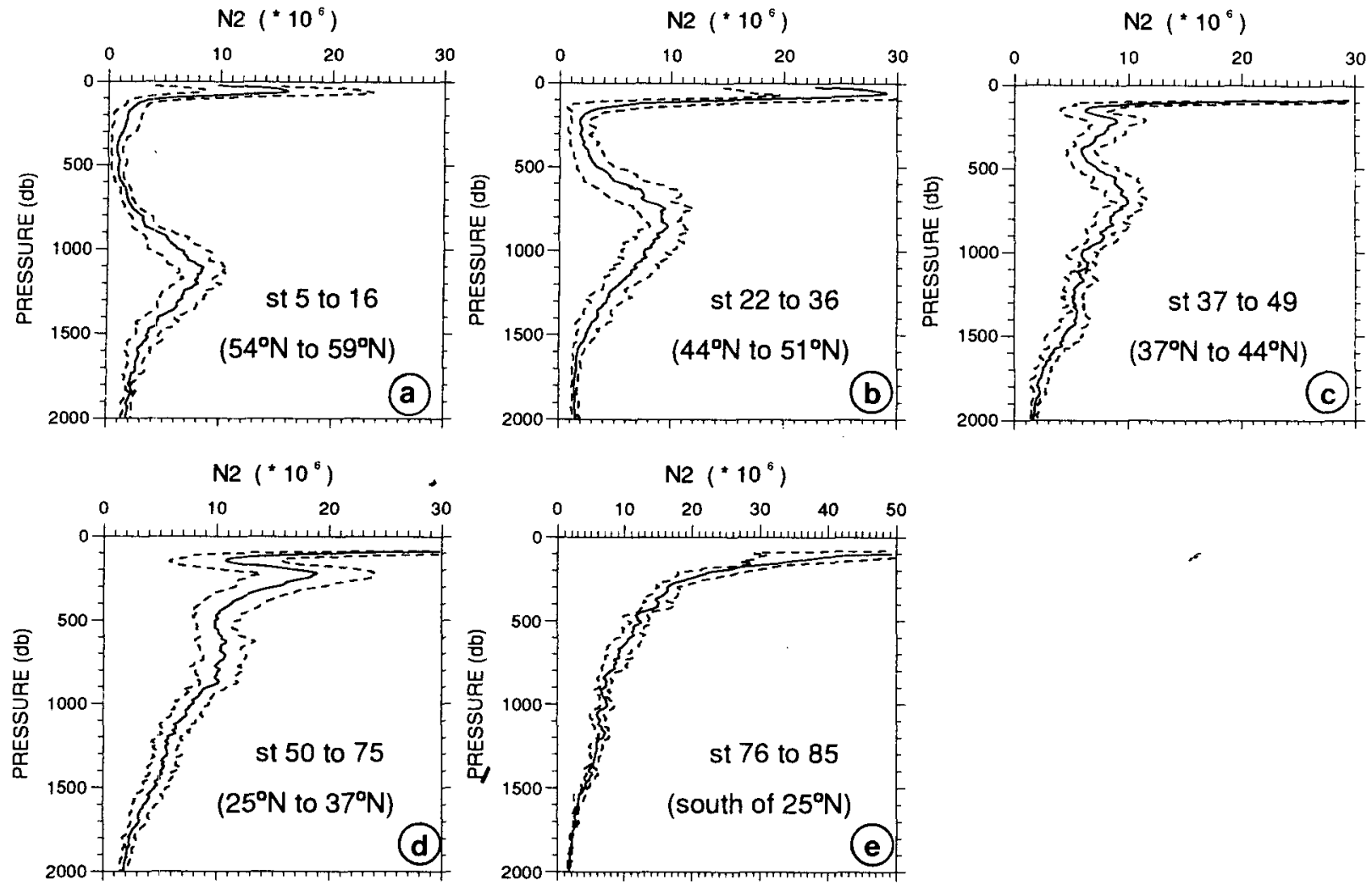

FIG. 11. Mean profiles of the squared Brunt-Väisälä frequency at five station groups, in units of $10^{-6}\left(\mathrm{rad} \mathrm{s}^{-1}\right)^{2}$. The broken lines are drawn at a standard deviation distance from the mean profiles. Note the different horizontal scale of plot (e).

seasonal thermocline at $52^{\circ} \mathrm{N}$. Such a pattern implies a net eastward transport at the upper levels, yet a slope reversal is observed above $700 \mathrm{db}$ between $25^{\circ}$ and $30^{\circ} \mathrm{N}$, which reveals the westward return flow of the subtropical gyre at these latitudes.

The northward density gradient prevailing in the upper $1000 \mathrm{db}$ could be indicative of "eastern boundary ventilation" (Pedlosky 1983). We should, however, not expect the depth-integrated zonal transports to vanish everywhere along the line as alongshore motions, such as the Canary Current or the northern outflow into the Norwegian Sea, undoubtedly cause a meridional redistribution of the incoming surface water. The other category of eastern boundary representations (Williams 1989; Huang 1990) in which a winter mixed layer is present, may also be checked against reality. The southward decrease of the mixed layer thickness is a basic feature of these models that enhances the ventilation rates toward more realistic values. Although such a behavior stands out in Fig. 6 , it was described in section 3.2 as being very localized, the quasi-totality of the thickness reduction taking place in the limited latitudinal band $40^{\circ} \mathrm{N}$ to $45^{\circ} \mathrm{N}$. Assuming that a southward flow component exists above the main pycnocline at these latitudes, this region should be very efficient in feeding the North Atlantic thermocline with recently ventilated water. Indeed, the distributions of dissolved oxygen on the isopycnal surfaces $\sigma_{T}=27.1$ and $\sigma_{T}=27.3$ shown by Pollard and $\mathrm{Pu}$ (1985) exhibit a northeastward gradient indicative of a reoxygenation of the NACW in the Bay of Biscay. In the mixed layer itself the steep isopycnals observed north of $45^{\circ} \mathrm{N}$ (Fig. 6 ), associated with extremely weak potential vorticity values, remind one of the vanishing vertical density gradients in the models. Below the mixed layer the density surfaces are still not level suggesting zonal flows to exist at the eastern boundary throughout the whole water column.

Inspection of the profiles of Brunt-Väisälä frequency along the section sheds light on the irregular southward shoaling of the winter mixed layer. The profiles are presented in five groups in Fig. 11 and the locations of their maxima in the upper thousand decibars reported on Fig. 6. North of $44^{\circ} \mathrm{N}$ the winter mixed layer rests on a well-defined main pycnocline as deep as $1100-1200 \mathrm{db}$ in Rockall Channel. South of $44^{\circ} \mathrm{N}$ this pycnocline still exists but the mixed layer is confined to shallower depths by another gradient. The main pycnocline seems pushed upward to about $600 \mathrm{db}$ between $37^{\circ}$ and $41^{\circ} \mathrm{N}$ by the MW intrusion, most pronounced at these latitudes. The stratification in the shallower pycnocline at about $250 \mathrm{db}$ increases south- 
ward (Figs. $11 \mathrm{c}, \mathrm{d}$ ), but this gradient disappears in its turn at $25^{\circ} \mathrm{N}$ at the boundary of SACW influence. The water above it (and below the seasonal pycnocline) was found particularly homogeneous in the vertical south of about $33^{\circ} \mathrm{N}$, with temperatures around $17^{\circ} \mathrm{C}$. This is the mode water that Siedler et al. (1987) showed to form through winter convection in the vicinity of Madeira. North of $33^{\circ} \mathrm{N}$ the vertical homogeneity somewhat disappears at the latitudes of the Gulf of Cadiz and is found again at lower temperatures $\left(\sim 14^{\circ} \mathrm{C}\right)$ at several stations west of Portugal. South of $25^{\circ} \mathrm{N}$ (Fig. 11e) both the main and shallower pycnocline have disappeared, although the ocean is very stratified at the upper levels.

On the whole, the density distribution along the Bord-Est line illustrates the Veronis (1973) remark on the difficulty of representing the ocean, even in a subbasin, by a two-layer model. The main pycnocline exists over most of the basin, but disappears south of about $30^{\circ} \mathrm{N}$, and is associated with a shallower one from $25^{\circ}$ to $40^{\circ} \mathrm{N}$. Their very existence, and position in the vertical, are influenced by the distribution of the water masses. The main pycnocline could be regarded as approximately isopycnal at about $\sigma_{\theta}=27.4$, except in the region of most intense MW outflow: there this isopycnal bulges upward, but the pycnocline does even more, and is found at $\sigma_{\theta}=27.3$. The shallower pycnocline is definitely more isobaric than isopycnic.

\section{b. Geostrophic velocities}

Geostrophic velocities representative of the largescale circulation have been computed through the thermal wind relation using alongline mean density gradients fitted linearly over 10 stations $(\sim 500 \mathrm{~km})$. Two solutions for the absolute velocities are presented both of which rely on the sole constraint of total mass conservation. The use of additional constraints is deferred to a separate study. The transports balancing the geostrophic flow are those associated with the ageostrophic Ekman drift across the line, the flow between the coast and the northern and southern ends of the section, and the exchanges with the Mediterranean Sea.

The distribution of the Ekman transport normal to the Bord-Est line (shown in Figs. 13a and 14a below) was computed from the Bunker wind field as reported in Isemer and Hasse (1987). We chose to use the May values, which lead to a significant westward Ekman drift south of $45^{\circ} \mathrm{N}$ only, amounting to $4.510^{6} \mathrm{~m}^{3} \mathrm{~s}^{-1}$ across the whole section.

It is generally acknowledged that the quasi totality of the Atlantic water flow into the Norwegian Sea takes place across the Wyville-Thomson ridge, but its intensity is still uncertain. The earlier estimates of less than $3 \times 10^{6} \mathrm{~m}^{3} \mathrm{~s}^{-1}$ from Ellett and Martin (1973) and 8 $\times 10^{6} \mathrm{~m}^{3} \mathrm{~s}^{-1}$ from Worthington (1976) seem to converge toward intermediate values. McCartney and Talley (1984) proposed $4.7 \times 10^{6} \mathrm{~m}^{3} \mathrm{~s}^{-1}$ and Ellett (1991, personal communication) suggests about $4 \times 10^{6}$ $\mathrm{m}^{3} \mathrm{~s}^{-1}$, of which $10^{6} \mathrm{~m}^{3} \mathrm{~s}^{-1}$ could be ascribed to the northward slope current (Huthnance 1986), while the remaining would be deeper Rockall Channel water transport. In using the latter value below we also assume the inflow to take place east of $8^{\circ} \mathrm{W}$, the approximate longitude of station 3 at the ridge crest. An opposite deep current containing overflow water from the Norwegian Sea must also be present (Ellett 1991) in the narrow Ymir Trough between stations 3 and 4. As this flow is not resolved by our large station spacing it should be included in the mass budget, but its transport of less than $0.3 \times 10^{6} \mathrm{~m}^{3} \mathrm{~s}^{-1}$ according to Ellett is within our error bar and was neglected.

We similarly neglected the net transport at Gibraltar, implying exact compensation between the flows in and out of the Mediterranean Sea, but assumed, when required in the layer analysis below, the amount of the exchange to be $10^{6} \mathrm{~m}^{3} \mathrm{~s}^{-1}$.

Quantifying the transport between the southernmost station $85\left(19^{\circ} 42^{\prime} \mathrm{N}, 20^{\circ} 56^{\prime} \mathrm{W}\right)$ and the coast is more hazardous. On the one hand, the slope current is known to carry SACW and AAIW northward at this latitude. On the other hand, most circulation schemes of the region place the eastern limit of the southward flowing Canary Current well inshore of station 85 . Here we also assumed compensation of both effects and supposed the net transport to be zero. Some support to this approximation may be found in a map by Shaffer (1976) showing an equal number of northward and southward flow lines at $300 \mathrm{~m}$, east of the location of station 85. Also, a map of the integrated volume transport from 0 to $800 \mathrm{~m}$ by Stramma (1984) shows but about $10^{6} \mathrm{~m}^{3} \mathrm{~s}^{-1}$ to flow southward east of this point. As this representation does not resolve the slope current, the error in assuming a zero net transport east of station 85 should be well below this value.

On the whole, the geostrophic transport across the Bord-Est line is therefore expected to be $8.5 \times 10^{6}$ $\mathrm{m}^{3} \mathrm{~s}^{-1}$, of which $4 \times 10^{6} \mathrm{~m}^{3} \mathrm{~s}^{-1}$ will eventually enter the Norwegian Sea, and $4.5 \times 10^{6} \mathrm{~m}^{3} \mathrm{~s}^{-1}$ will return to the west through the Ekman layer. This net transport estimate is admittedly a crude one, probably uncertain to within $10 \%-20 \%$. Given this value, a first solution for the absolute velocities was computed on the basis that a "level" of no motion exists at the potential temperature $2.5^{\circ} \mathrm{C}$ over that part of the section deep enough for such low temperature to be present. This level, which corresponds to pressures around $3200 \mathrm{db}$, was chosen for being close to that used in other studies of the same region $\left[\theta=2.5^{\circ} \mathrm{C}\right.$ in McCartney (1992) or $3500 \mathrm{db}$ in Saunders (1987)]. It cannot of course be extended to the shallower Rockall Channel. There the (isothermal) level of no motion was adjusted to a value $\left(6^{\circ} \mathrm{C}\right)$, which provided the required $8.5 \times 10^{6}$ $\mathrm{m}^{3} \mathrm{~s}^{-1}$ transport. This solution (referred to as the LNM solution in the following) is shown in Fig. 12a. 

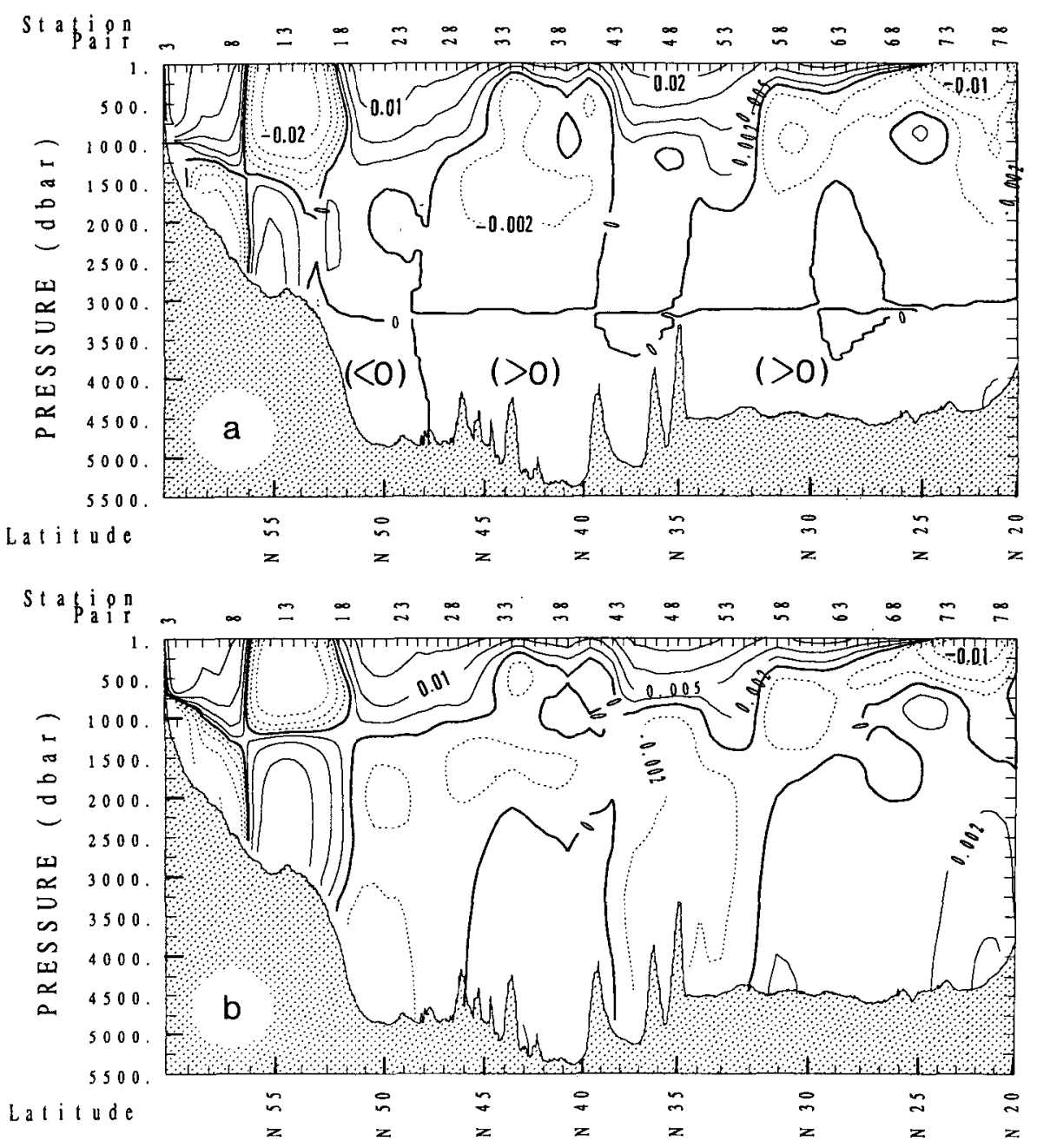

FIG. 12. The two solutions for the large-scale geostrophic velocity across the Bord-Est line: LNM solution (a); ZF solution (b). Velocities are in meters per second and positive eastward.

The absolute velocities in the second solution were determined by forcing the vertically integrated geostrophic transport to feed the local Ekman transport and, at northern latitudes, the Norwegian Sea inflow. The $4 \times 10^{6} \mathrm{~m}^{3} \mathrm{~s}^{-1}$ required for the latter were partitioned into $3 \times 10^{6} \mathrm{~m}^{3} \mathrm{~s}^{-1}$ distributed uniformly from $53^{\circ} \mathrm{N}$ to the Wyville-Thomson ridge and supposed to carry Rockall Channel water, and $10^{6} \mathrm{~m}^{3} \mathrm{~s}^{-1}$ from $40^{\circ}$ to $50^{\circ} \mathrm{N}$ to account for the slope current supply. This solution is shown in Fig. 12b. Being a generalization of the no-net-zonal-flux condition it is referred to as the "zonal-flux" (ZF) solution in the following.

Both solutions are qualitatively similar in Rockall Channel and above $\sim 1000 \mathrm{db}$ over the rest of the section. They differ significantly at greater depths. The line of no motion in Rockall Channel is a reminder of the pronounced pycnocline present at similar pressures (Fig. 11a). Above it the $9^{\circ}$ mode water, a part of which feeds the Norwegian Sea, follows a basic anticyclonic circulation. The deep layer below, which is mainly filled with LSW, shows a reverse cyclonic flow. The presence of LSW was shown to be most pronounced between $50^{\circ}$ and $54^{\circ} \mathrm{N}$ where the closed isocontours on Fig. $3 \mathrm{~b}$ were interpreted as a cross section of an eastward flowing tongue. An eastward flow is indeed observed at these depths in the latitudinal band $51^{\circ}-56^{\circ} \mathrm{N}$, a confirmation that the LSW vein feeds the cyclonic circulation in Rockall Channel and is probably reinforced by the latter at its northern flank. South of $51^{\circ} \mathrm{N}$ the LSW seen to extend to $45^{\circ} \mathrm{N}$ on Fig. $3 \mathrm{~b}$ is associated with negative velocities that could be the signature of a southwestward return flow.

In the subtropical region north of $25^{\circ} \mathrm{N}$ a ubiquitous eastward current stands out above $\sim 300 \mathrm{db}$. This flow is most intense and deepest (to $1000 \mathrm{db}$ in the $\mathrm{ZF}$ solution and to $3000 \mathrm{db}$ in the LNM one) in the two latitudinal bands $45^{\circ}-51^{\circ} \mathrm{N}$ and $32^{\circ}-39^{\circ} \mathrm{N}$. In the intervening region $\left(39^{\circ}-49^{\circ} \mathrm{N}\right)$ the mainly westward ve- 

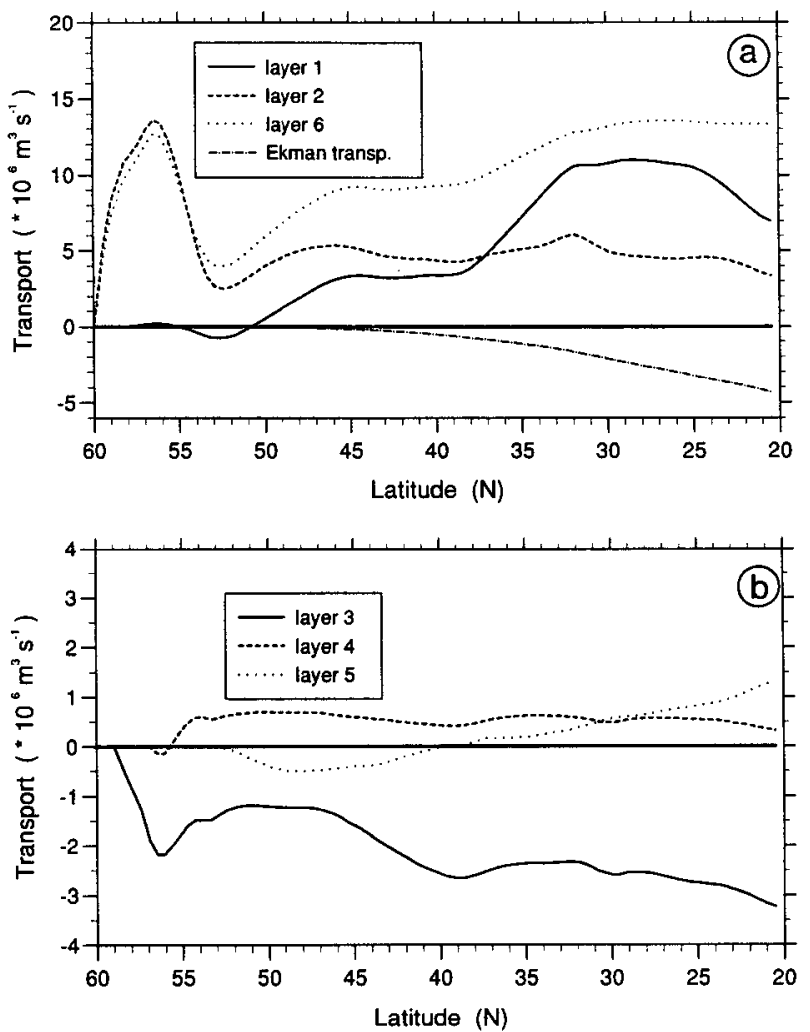

FIG. 13. The meridionally integrated geostrophic transports (positive eastward) across the Bord-Est line, in the six layers defined in the text, for solution LNM: layer 1 (surface $<\sigma_{\theta}<27.25$ ), layer 2 $\left(27.25<\sigma_{0,1}<32.35\right)$, layer $3\left(32.35<\sigma_{1,2}<36.96\right)$, layer 4 ( 36.96 $\left.<\sigma_{2.4}<45.85\right)$, layer $5\left(45.85<\sigma_{4}<\right.$ bottom); layer 6 is the winter mixed layer as displayed in Fig. 6. The meridionally integrated Ekman transport in May (Isemer and Hasse 1987) is also displayed in (a) for comparison.

locities observed around $1000 \mathrm{db}$ could be indicative of the entry of MW into the basin. The westward return flow of the subtropical gyre is most pronounced and reaches the surface south of $25^{\circ} \mathrm{N}$ in the region of influence of SACW. At depth it is observed more to the north, as far as $32^{\circ} \mathrm{N}$ at $900 \mathrm{db}$. There it must be fed by the northward alongshore undercurrent, which was suggested as the likely carrier of AAIW to such latitudes.

The LNM solution predicts as expected an eastward flow of bottom water south of $48^{\circ} \mathrm{N}$ and a westward return flow in the Porcupine Abyssal Plain, the "large scale" velocities in this layer being everywhere weaker than $2 \times 10^{-3} \mathrm{~m} \mathrm{~s}^{-1}$. The $\mathrm{ZF}$ solution rather suggests the bottom circulation to be dominated by two cyclonic cells separated by the topographic barriers edging the Tagus Abyssal Plain. In the southern cell velocities are eastward south of $32^{\circ} \mathrm{N}$ with some intensification against the Cape Verde continental rise, and westward in the Seine and Horseshoe Abyssal Plains. The flow pattern in the northern cell is as described in section
5 , the AABW entering the Bay of Biscay south of the Charcot Seamounts and flowing back westward north of them. The northern boundary current is visualized by the $0.002 \mathrm{~m} \mathrm{~s}^{-1}$ contour, but due to the heavy lateral smoothing seems larger and less intense than suggested by the steep isopleths of Fig. 10.

\section{Transports}

The transports associated with the above solutions have been computed in five layers separated by the isopycnal surfaces $\sigma_{\theta}=27.25, \sigma_{1}=32.35, \sigma_{2}=36.96$, and $\sigma_{4}=45.85$. The upper layer extends to the surface and contains the central water (Fig. $3 \mathrm{a}$ ). The MW, SAIW, and the core of AAIW are in layer 2, and the LSW is present north of $45^{\circ} \mathrm{N}$ in layer 3 . Layer 4 contains the less well-defined lower deep water and layer 5, whose upper limit lies between 3500 and $4000 \mathrm{db}$, contains the diluted AABW. The winter mixed layer defined in Fig. 6 was considered as a sixth layer. The transports integrated southward from station 3 (on the crest of the Wyville-Thomson ridge) in each layer and for both solutions are shown in Figs. 13 and 14.

Contributions of the two latitudinal bands $45^{\circ}-51^{\circ} \mathrm{N}$ and $32^{\circ}-39^{\circ} \mathrm{N}$ to the eastward transport of NACW compare well in both solutions and amount, respectively, to about $4 \times 10^{6} \mathrm{~m}^{3} \mathrm{~s}^{-1}$ and $7 \times 10^{6} \mathrm{~m}^{3} \mathrm{~s}^{-1}$.
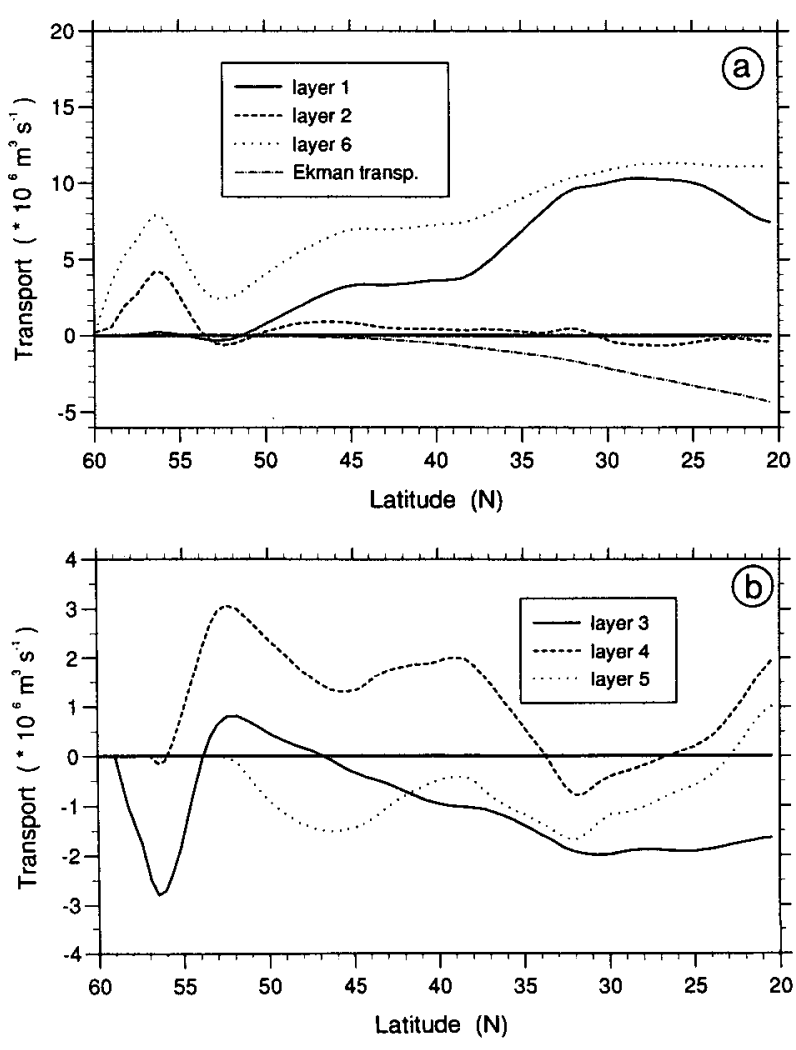

FIG. 14. Same as Fig. 13 but for solution ZF. 
TABLE 1. Meridionally integrated transports across the Bord-Est line (in units of $10^{6} \mathrm{~m}^{3} \mathrm{~s}^{-1}$ ), from the Wyville-Thomson ridge to $20^{\circ} \mathrm{N}$, in each layer and for the whole water column.

\begin{tabular}{lccccccc}
\hline \hline & & \multicolumn{7}{c}{ Layer number } \\
\cline { 2 - 8 } Solution & 1 & 2 & 3 & 4 & 5 & Total & 6 \\
\hline LNM & 6.9 & 3.3 & -3.3 & 0.3 & 1.3 & 8.5 & 13.3 \\
ZF & 7.4 & -0.4 & -1.6 & 2.1 & 1.0 & 8.5 & 11.1 \\
\hline
\end{tabular}

The westward flow of mixed central waters south of $25^{\circ} \mathrm{N}$ is a third well-defined feature in this layer: the LNM and ZF solutions predict for it transports of 4 $\times 10^{6} \mathrm{~m}^{3} \mathrm{~s}^{-1}$ and $3 \times 10^{6} \mathrm{~m}^{3} \mathrm{~s}^{-1}$, respectively.

The two solutions present more significant differences in layer 2: the LNM one exhibits a more intense circulation in the Rockall Channel with an eastward transport of $13.6 \times 10^{6} \mathrm{~m}^{3} \mathrm{~s}^{-1}$ north of $56^{\circ} \mathrm{N}$ only partly compensated by a westward flow of $11 \times 10^{6}$ $\mathrm{m}^{3} \mathrm{~s}^{-1}$. This leaves a $2.6 \times 10^{6} \mathrm{~m}^{3} \mathrm{~s}^{-1}$ excess of Rockall Channel water close to the $3 \times 10^{6} \mathrm{~m}^{3} \mathrm{~s}^{-1}$ required to feed the Norwegian Sea. In the same layer a westward transport of less than $10^{6} \mathrm{~m}^{3} \mathrm{~s}^{-1}$ exists on both solutions in the region $38^{\circ}$ to $47^{\circ} \mathrm{N}$, which could be interpreted as the entry of MW into the basin. Comparable transports of greater southward extension exist in layer 3. South of $32^{\circ} \mathrm{N}$ in layer 2, solutions LNM and ZF also show westward transports of $3 \times 10^{6} \mathrm{~m}^{3} \mathrm{~s}^{-1}$ and $10^{6} \mathrm{~m}^{3} \mathrm{~s}^{-1}$, respectively, possibly associated with the AAIW. To the north, the recirculation of LSW (layer 3 ) in Rockall Channel amounts to $2 \times 10^{6} \mathrm{~m}^{3} \mathrm{~s}^{-1}$ and $3 \times 10^{6} \mathrm{~m}^{3} \mathrm{~s}^{-1}$. The results are very different for the two solutions in layer 4 with virtually no structure along the LNM curve. In layer 5, the two cells already mentioned, and at more intense northern boundary current $\left(-1.5 \times 10^{5} \mathrm{~m}^{3} \mathrm{~s}^{-1}\right.$ as compared with $-0.5 \times 10^{6}$ $\mathrm{m}^{3} \mathrm{~s}^{-1}$ ) stand out in the ZF solution.

Table 1 shows for each layer the integrated transport from the Wyville-Thomson ridge to the southern end of the section. The values in layers 1 to 5 add up to $8.5 \times 10^{6} \mathrm{~m}^{3} \mathrm{~s}^{-1}$ for both solutions, as imposed. The meridionally integrated transports are eastward for both solutions in layers 1,4 , and 5 , and westward in layer 3 . The only sign difference is in layer 2 , and the reason for it may be traced back on Figs. 13 and 14 to the Rockall Channel region. The intense lateral density gradients present there below $1000 \mathrm{db}$ render the transport computations very sensitive to small variations of the depth of no motion. In the above we pointed out the significant eastward transport (13.6 $\times 10^{6} \mathrm{~m}^{3} \mathrm{~s}^{-1}$ ) predicted north of $56^{\circ} \mathrm{N}$ in layer 2 by the LNM solution and the only partial return flow south of it. Due to a shallower depth of no motion the northern eastward transport of layer 2 water is limited to $4 \times 10^{6} \mathrm{~m}^{3} \mathrm{~s}^{-1}$ in the $\mathrm{ZF}$ solution, and is totally compensated by the return flow. This solution is clearly less satisfactory than the LNM one with regard to the
Norwegian Sea supply, although the constraint of a $3 \times 10^{6} \mathrm{~m}^{3} \mathrm{~s}^{-1}$ transport excess was imposed in Rockall Channel: this excess is indeed observed in the deep layers not connected with the Norwegian Sea. Such shortfall of the ZF solution in Rockall Channel most certainly reflects a dominant meridional-rather than vertical-redistribution of the incoming zonal flows in the eastern boundary layer. This led us to use the LNM solution for a tentative surface to bottom volume transport budget pictured in Fig. 15.

To be closed, this budget had to be completed by diapycnal transports between layers. Thus, an upwelling of $1.6 \times 10^{6} \mathrm{~m}^{3} \mathrm{~s}^{-1}$ from layer 2 adds up to the $6.9 \times 10^{6} \mathrm{~m}^{3} \mathrm{~s}^{-1}$ eastward geostrophic transport of layer 1 to feed the Ekman drift $\left(4.5 \times 10^{6} \mathrm{~m}^{3} \mathrm{~s}^{-1}\right)$, the inflows into the Mediterranean Sea $\left(10^{6} \mathrm{~m}^{3} \mathrm{~s}^{-1}\right)$ and the Norwegian Sea (the $10^{6} \mathrm{~m}^{3} \mathrm{~s}^{-1}$ contribution of the northward slope current), and a downward entrainment of $2 \times 10^{6} \mathrm{~m}^{3} \mathrm{~s}^{-1}$ to produce mixed MW in the Gulf of Cadiz (Zenk 1975). This entrained water and the outflow at Gibraltar $\left(10^{6} \mathrm{~m}^{3} \mathrm{~s}^{-1}\right)$ in their turn

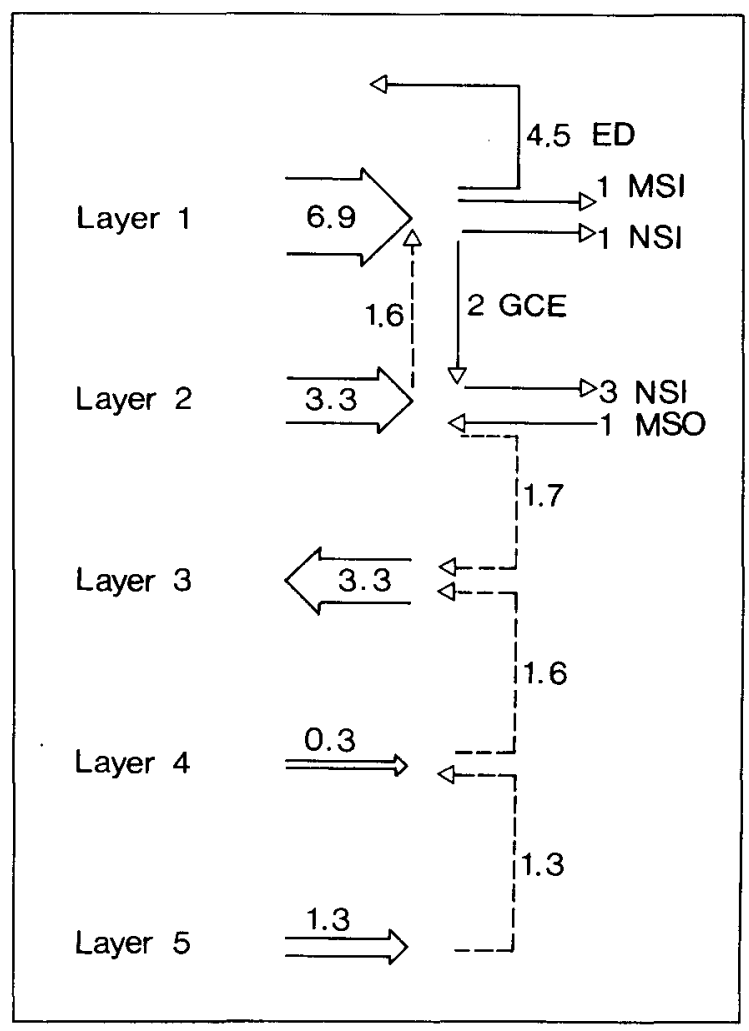

Fig. 15. Meridionally integrated volume transport budget of the region east of the Bord-Est line, for the LNM solution. Transports are in units of $10^{6} \mathrm{~m}^{3} \mathrm{~s}^{-1}$. Thick arrows are the computed geostrophic transports across the section in each layer. Thin continuous arrows are specified transports in or out of each layer. Broken-line arrows are the inferred exchanges between layers; ED stands for Ekman drift; MSI: Mediterranean Sea inflow; NSI: Norwegian Sea inflow; GCE: Gulf of Cadiz entrainment; and MSO: Mediterranean Sea outflow. 
reinforce the eastward geostrophic flow of layer 2 to a total of $6.3 \times 10^{6} \mathrm{~m}^{3} \mathrm{~s}^{-1}$ for the Norwegian Sea inflow $\left(3 \times 10^{6} \mathrm{~m}^{3} \mathrm{~s}^{-1}\right.$ of layer 2 water), and the up- and downwellings toward layers 1 and 3 . The geostrophic transports in layers 3-5 similarly imply upwellings of $1.6 \times 10^{6} \mathrm{~m}^{3} \mathrm{~s}^{-1}$ and $1.3 \times 10^{6} \mathrm{~m}^{3} \mathrm{~s}^{-1}$ along the eastern boundary at the interfaces between layers 3 and 4 , and 4 and 5.

Vertical exchanges of both directions exist between layers 1 and 2. The downward entrainment of upper water in the Gulf of Cadiz is a particular mechanism contributing to the eastern boundary ventilation ( $\mathrm{Ped}$ losky 1983). The upward transport of $1.6 \times 10^{6} \mathrm{~m}^{3} \mathrm{~s}^{-1}$ could perhaps be associated with the upwelling known to occur in the area off northwest Africa, and active at the season of the cruise (Wooster et al. 1976). Assuming this upwelling to take place between $20^{\circ}$ and $32^{\circ} \mathrm{N}$, our transport value would imply a mean vertical velocity of about $3 \times 10^{-6} \mathrm{~m} \mathrm{~s}^{-1}$ between the Bord-Est line and the continental slope.

The $1.3 \times 10^{6} \mathrm{~m}^{3} \mathrm{~s}^{-1}$ and $1.6 \times 10^{6} \mathrm{~m}^{3} \mathrm{~s}^{-1}$ upward transports at the two lower interfaces illustrate the upwelling of deep and bottom waters as predicted by Stommel and Arons (1960). The area between the Bord-Est line and the 4000-m isobath at the continental rise was estimated to about $2 \times 10^{6} \mathrm{~km}^{2}$, leading to an averaged vertical velocity of $6.5 \times 10^{-7} \mathrm{~m} \mathrm{~s}^{-1}$ at the top of layer 5. This is a rather high value compared to those generally admitted for the ocean interior, such as the $1.4 \times 10^{-7} \mathrm{~m} \mathrm{~s}^{-1}$ of Munk (1966), but similar estimates for the vertical velocity at $4000 \mathrm{~m}$ were reported by Barton and Hill (1989). The particular setting of the deep northeast Atlantic basin acting as a cul-de-sac for the northward progression of AABW, could explain such values.

Knowledge of the transports across the Bord-Est line allows us, through mass conservation, to estimate the meridional flow in the eastern boundary layer. This computation was carried out for layer 1 , for which the results were weakly dependent on the solution, by integrating the conservation equation northward from $20^{\circ} \mathrm{N}$ where the meridional transport east of the line was assumed to vanish. In Fig. 16 the $6.9 \times 10^{6} \mathrm{~m}^{3} \mathrm{~s}^{-1}$ of net eastward transport in layer 1 is schematically distributed into two eastward components with values of $3.4 \times 10^{6} \mathrm{~m}^{3} \mathrm{~s}^{-1}$ and $7.6 \times 10^{6} \mathrm{~m}^{3} \mathrm{~s}^{-1}$ in the latitudinal bands $45^{\circ}-52^{\circ} \mathrm{N}$ and $32^{\circ}-39^{\circ} \mathrm{N}$, and a westward component of $4.1 \times 10^{6} \mathrm{~m}^{3} \mathrm{~s}^{-1}$ from $20^{\circ}$ to $27^{\circ} \mathrm{N}$. The transport in each of these domains was assumed uniformly distributed in latitude. We used the Bunker distribution for the Ekman transport $\left(4.5 \times 10^{6}\right.$ $\mathrm{m}^{3} \mathrm{~s}^{-1}$ ), and positioned the inflow at Gibraltar and the downward entrainment in the Gulf of Cadiz between $36^{\circ}$ and $38^{\circ} \mathrm{N}$. The $1.6 \times 10^{6} \mathrm{~m}^{3} \mathrm{~s}^{-1}$ upwelling from layer 2 is assumed uniformly distributed south of $32^{\circ} \mathrm{N}$.

A $10^{6} \mathrm{~m}^{3} \mathrm{~s}^{-1}$ northward slope current exists at $52^{\circ} \mathrm{N}$ where the integration was stopped. The $3.4 \times 10^{6}$ $\mathrm{m}^{3} \mathrm{~s}^{-1}$ zonal transport north of $45^{\circ} \mathrm{N}$ must be an ex-

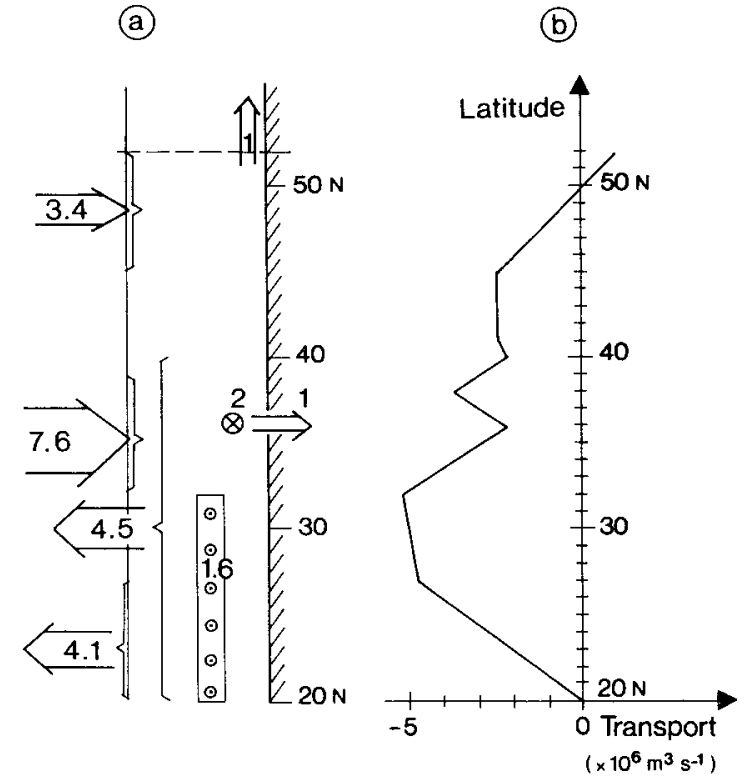

FIG. 16. Schematic budget of volume transport in layer 1 (a) and inferred meridional transports in this layer east of the Bord-Est line, positive northward (b).

tension of the North Atlantic drift to the eastern boundary. It may contribute to the northward slope current, but most of it is seen (Fig. 16b) to feed a 2.4 $\times 10^{6} \mathrm{~m}^{3} \mathrm{~s}^{-1}$ southward transport off the Iberian Peninsula, probably associated with the so-called Portuguese Current. In doing so it must cross that region where the base of the winter mixed layer was seen to be steepest, and thus be an important factor for the ventilation of the thermocline of the eastern North Atlantic.

In our budget the $7.6 \times 10^{6} \mathrm{~m}^{3} \mathrm{~s}^{-1}$ eastward transport between $32^{\circ}$ and $39^{\circ} \mathrm{N}$ is utilized to feed the inflow into the Mediterranean Sea, the downward entrainment in the Gulf of Cadiz, the Ekman drift, and most of the Canary Current. The $1.6 \times 10^{6} \mathrm{~m}^{3} \mathrm{~s}^{-1}$ upwelling provides an additional contribution to the Canary Current, which shows a maximum value of about 5 $\times 10^{6} \mathrm{~m}^{3} \mathrm{~s}^{-1}$ between $28^{\circ}$ and $32^{\circ} \mathrm{N}$. This transport, which corresponds to a surface layer $\left(\sigma_{\theta}<27.25\right)$ of approximate thickness $750 \mathrm{~m}$, compares well with the 4 to $5\left(\times 10^{6} \mathrm{~m}^{3} \mathrm{~s}^{-1}\right)$ observed at the same location on a map of the $0-800 \mathrm{~m}$ geostrophic transport by Stramma (1984). The question of the origin of the eastward flow between $32^{\circ}$ and $39^{\circ} \mathrm{N}$ arises. This transport is undoubtedly partly fed by the Azores Current, but its northern part is likely to originate north of the Azores Archipelago as suggested by geostrophic flow patterns in Maillard (1986).

Except for the imposed Gulf of Cadiz entrainment there is no sign of eastern boundary ventilation in Fig. 16. A reason may be that the above budgets are representative of a spring period. Annual budgets should 
also include downward transports from layer 1 associated with winter convection and the ensuing water mass conversions known to occur in Rockall Channel and the Bay of Biscay. Replacing in Fig. 15 the May Ekman drift value of $4.5 \times 10^{6} \mathrm{~m}^{3} \mathrm{~s}^{-1}$ by the annual one of $2.7 \times 10^{6} \mathrm{~m}^{3} \mathrm{~s}^{-1}$ reduces the net diapycnal transport to $-0.2 \times 10^{6} \mathrm{~m}^{3} \mathrm{~s}^{-1}$. This does not mean that the vertical exchanges have almost disappeared at all latitudes but, more likely, that over a year the upwelled transport is a little more than compensated by the downward motions associated with water mass conversion at higher latitudes. As the sole mass conservation constraint used here does not allow separation of positive and negative contributions, it was thought better to present the spring budget.

Finally, the contribution of the winter mixed layer to the eastward transport was computed for reference to those thermocline models in which such a layer exists. That contribution amounts to $13.3 \times 10^{6} \mathrm{~m}^{3} \mathrm{~s}^{-1}$ in the LNM solution (Table 1). This incoming transport is expected to feed the Norwegian Sea inflow (4 $\left.\times 10^{6} \mathrm{~m}^{3} \mathrm{~s}^{-1}\right)$ and the westward Ekman drift north of $24^{\circ} \mathrm{N}$ where the winter mixed layer exists $\left(3.5 \times 10^{6}\right.$ $\mathrm{m}^{3} \mathrm{~s}^{-1}$ ). It also contributes to the MW inflow and the Gulf of Cadiz entrainment by a fraction that we roughly estimated to $50 \%\left(0.5 \times 10^{6} \mathrm{~m}^{3} \mathrm{~s}^{-1}\right.$ and $\left.10^{6} \mathrm{~m}^{3} \mathrm{~s}^{-1}\right)$ on account of the limited depth of the mixed layer at these latitudes $(200 \mathrm{~m})$. After subtraction of these quantities we are left with $4.3 \times 10^{6} \mathrm{~m}^{3} \mathrm{~s}^{-1}$ of water leaving the mixed layer east of the Bord-Est line to ventilate the interior of the subtropical gyre. Using the annual Ekman drift would increase this transport to $5.8 \times 10^{6} \mathrm{~m}^{3} \mathrm{~s}^{-1}$. These are again net quantities, the real ventilation rate being probably still higher, if opposite upwelling effects are to be balanced. It is remarkable that the winter mixed layer budget shows such an excess available for gyre ventilation whereas upwelling had to be invoked to balance the layer 1 deficit above. Despite the large uncertainties of the transport estimates, this could be a confirmation that meridional transfer of fluid across the sloping mixed layer is a more efficient ventilation mechanism than vertical redistribution of the incoming zonal flow.

\section{Mesoscale structures}

Although the Bord-Est section was primarily aimed at describing the large-scale hydrography, a number of mesoscale eddies were discovered in spite of the relatively coarse spatial sampling. The individual sightings (Fig. 1) show that the observations fall into two broad categories, namely, winter intensified anticyclones found between $45^{\circ}$ and $54^{\circ} \mathrm{N}$, and lenses of MW (meddies) present between $30^{\circ}$ and $37^{\circ} \mathrm{N}$.

\section{a. The winter intensified anticyclones}

Fortunately, resolution of the mesoscale was made possible in the northern half of the section owing to closely spaced XBTs allowing construction of a detailed temperature section (Fig. 17a). Most striking is the presence of four eddies centered at stations $18,23,26$, and 31 , with core temperatures between $10.2^{\circ}$ and $11^{\circ} \mathrm{C}$. On the whole, these temperatures are higher than those of the surroundings implying an anticyclonic rotation of the four vortices. The oxygen and nitrate sections (Figs. 17b,c) suggest the cores of the structures to have been in contact with the atmosphere during the previous winter and provide an illustration that winter convection chooses the sites of anticyclonic vorticity for reaching deep into the ocean. Although the surface density fluxes are of a larger scale, it is the low stratification found in the anticyclones that allows the deep convection to occur preferentially there. If, for example, $B$ units of buoyancy are removed at the surface from a linear density gradient, the convection depth is simply $\left(2 B / \rho_{z}\right)^{1 / 2}$ showing the desired effect.

Richardson (1993) made a census of eddies as revealed from SOFAR float data, and we suggest that the structures observed here could have some common features with the anticyclonic "loopers" found south of the Gulf Stream that may occasionally be filled with
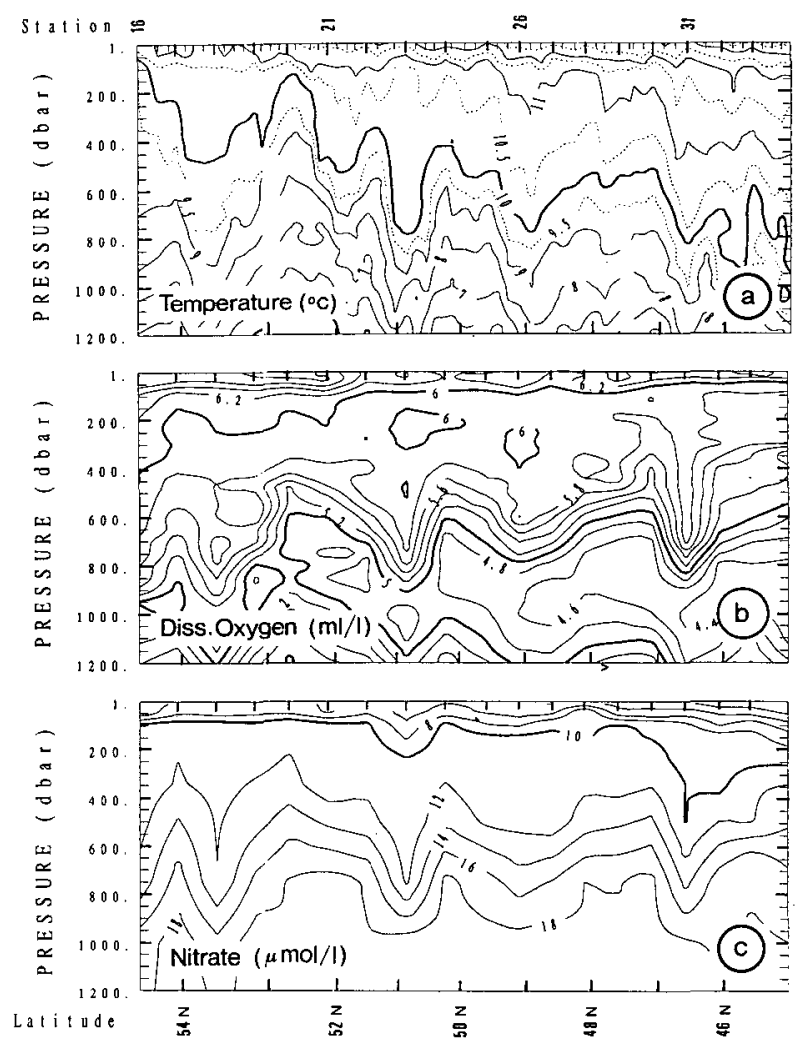

FIG. 17. Vertical distributions of temperature (a), dissolved oxygen (b), and nitrate (b) in the region where winter intensified anticyclones were observed. The temperature distribution uses both CTD and XBT data, the latter having been acquired at intervals of $10 \mathrm{nmi}$ between the CTD stations by the French Service Hydrographique et Océanographique de la Marine (SHOM). 
new $18^{\circ} \mathrm{C}$ Water. The anticyclonic loopers were observed to originate at instabilities of the stream (along with the more widely known cold core rings of opposite rotation ) suggesting similar south (east)ward eddy detachment to occur in the northeast Atlantic at the polar front a few hundreds of kilometers from where the anticyclones are observed. A map of the distribution of surface eddy kinetic energy in Krauss and Käse (1984) does reveal an extension of high energy levels from the North Atlantic Current into this region. Ensuing winter convection would then cause the near-surface properties to be mixed downward in the eddies to several hundreds of meters as observed here. Among other formation hypotheses, we should also mention the generation of slope water eddies described by Pingree and Le Cann (1992). Warm slope water carried by the poleward current along the eastern boundary appears inside anticyclonic eddies formed at the continental slope, as they migrate offshore. The particular structure observed by these authors originated at about $45^{\circ} \mathrm{N}$ and had core characteristics $\theta \approx 12.95^{\circ} \mathrm{C}$ and 26.95 $<\rho_{\theta}<27.0$ above $300 \mathrm{~m}$. A single cooling season cannot transform such characteristics into those of our
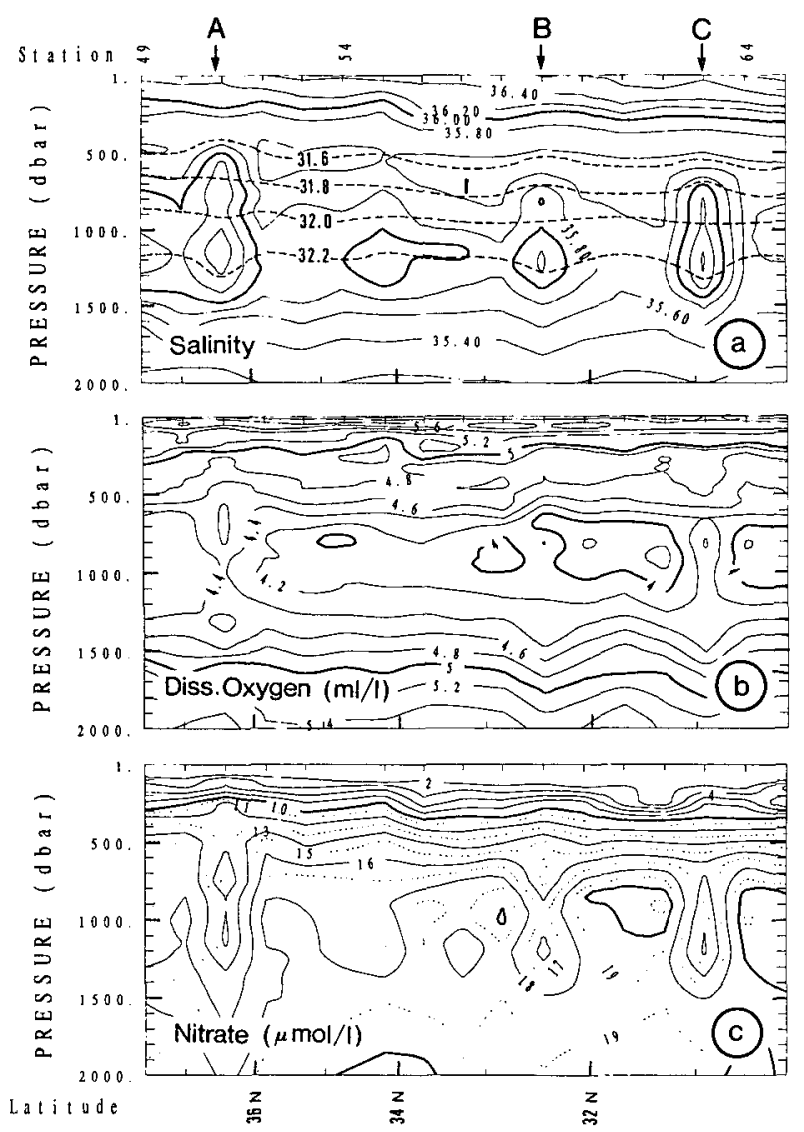

FIG. 18. Vertical distributions of salinity, with four superposed isopycnals (a), dissolved oxygen (b), and nitrate (c) in the meddies region.

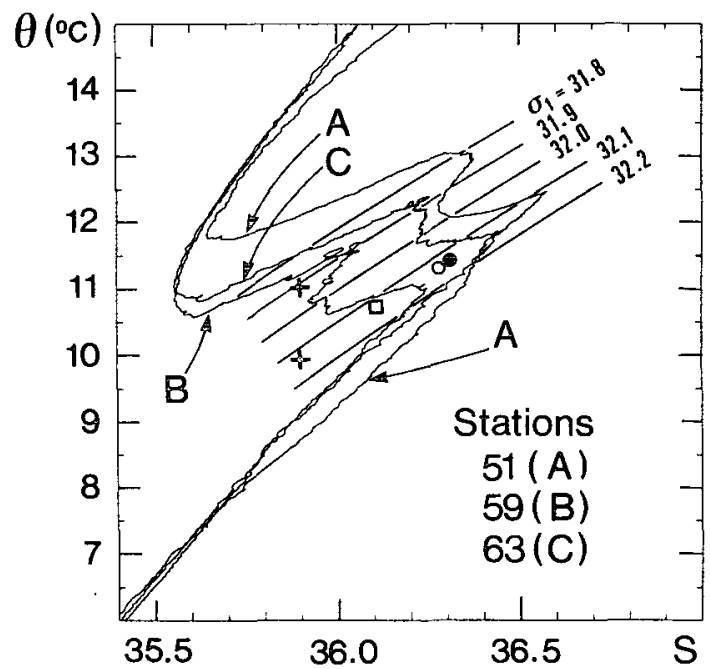

FIG. 19. $\theta-S$ relation of the three observed meddies showing their double-core structure. Also reported are the salinity maxima in a few other meddy observations. $(+)$ : Meddy Birgit at $22^{\circ} \mathrm{N}, 26^{\circ} 04^{\prime} \mathrm{W}$ in Zenk et al. (1991). ( $\square$ ): Station TT083 (Tropical Atlantic Study) at $25^{\circ} 40^{\prime} \mathrm{N}, 27^{\circ} 49^{\prime} \mathrm{W}$. (O) and (-): Stations TT060 at $31^{\circ} \mathrm{N}$, $26^{\circ} 39^{\prime} \mathrm{W}$ and TT090 at $30^{\circ} 57^{\prime} \mathrm{W}, 22^{\circ} 38^{\prime} \mathrm{W}$ (North Atlantic Study).

winter intensified anticyclones, yet denser slope water eddies formed farther north, if any, could be an alternative to the polar front anticyclonic loopers.

Whatever the origin of the anticyclonic eddies, these observations show that an important form of ventilation and water mass renewal occurs at the mesoscale rather than at the large scale. In terms of nondimensional numbers, and for further reference, these eddies possess Rossby numbers of order 0.1 (speeds of 20 $\mathrm{cm} \mathrm{s}^{-1}$ and radius of $20 \mathrm{~km}$ ) and relatively low Burger numbers $(N h / f L)^{2}$ from 0.1 to 0.2 due to BruntVäisälä frequencies around $4 \times 10^{-3} \mathrm{rad} \mathrm{s}^{-1}$ (Fig. 11b).

\section{b. The meddies}

There is now abundant literature on meddies and our observation of three of them (station 55 may have been done at the rim of a fourth one), each sampled by one single station, will admittedly not add much to our knowledge of the behavior of individual structures. Of more interest is the quasi-synoptic view provided by Bord-Est of a series of them in their large-scale environment.

Figure 18 presents expanded vertical sections of salinity, dissolved oxygen, and nitrates for the meddy region, and Fig. 19 displays the $\theta-S$ diagrams at stations 51,59 , and 63 within the three meddies, which we respectively name $A, B$, and $C$ in the following. The nitrate section illustrates the particularly well-defined meddy signature, while the dissolved oxygen section shows how the lenses appear as high anomalies against the basinwide layer of intermediate oxygen minimum. Most striking on both figures is their double core struc- 
ture. The occurrence of double salinity maxima in the Mediterranean outflow is well known and such profile types have already been reported in meddies (Richardson et al. 1989; Zenk et al. 1991). This is, however, not a general characteristic of these structures as several other observations are devoid of the upper core. The densities at which the maxima appear are pretty constant at $31.85 \leqslant \sigma_{z} \leqslant 31.90$ and $32.15 \leqslant \sigma_{1} \leqslant 32.20$ in these and other (Fig. 19) meddies. They compare well with the Portugal proximity values of 31.85 and 32.25 quoted by Zenk and Armi (1990) for the MW outflow, although the meddy lower maxima are slightly lighter. The double core signature of meddies, when it exists, must therefore have been acquired in the formation region, and the constant densities for the several observations would plead in favor of a mainly isopycnal mixing during their migration through the ocean interior.

The isopycnic lines superimposed on Fig. 18a reveal the lens-shaped structure typical of water mass intrusions. The sign reversal of the density anomaly in the lenses occurs at different levels depending on the relative strength of the two cores: at $\sigma_{1} \approx 32.0(p \approx 950$ $\mathrm{db})$ in meddies $\mathrm{B}$ and $\mathrm{C}$, and at $\sigma_{1} \approx 31.85(p \approx 700$ $\mathrm{db}$ ) in meddy $A$ showing a relatively stronger upper core. In all cases this level, which is also that of the geostrophic velocity maximum, is shallower than that of the lower core (and overall) salinity maximum found between 1100 and $1200 \mathrm{db}$. The geostrophic velocities computed between stations $51,59,63$, and the neighboring ones (relative to $3000 \mathrm{db}$ ) can only be underestimates of the real ones, due to the poor spatial resolution. We indeed found maxima around $10 \mathrm{~cm} \mathrm{~s}^{-1}$ for the three meddies, far below the values in excess of $30 \mathrm{~cm} \mathrm{~s}^{-1}$ reported in other studies (Richardson et al. 1989).

Our data cannot tell much about the origin of these lenses, yet, as the MW outflow proceeds along the northern continental slope of the Gulf of Cadiz, double maxima profiles are only encountered at, and west of, the Portimao Canyon at $8^{\circ} 30^{\prime} \mathrm{W}$ southeast of Cape St. Vincent (Madelain 1970; Howe et al. 1974). The lower core salinity maxima are $36.56,36.24$, and 36.43 psu at meddies A, B, and C, respectively. Inspection of the literature and data from the subsequent Bord-Est 3 cruise (Arhan et al. 1991a), shows that the salinity in the coastly trapped vein of $\mathrm{MW}$ is close to 36.6 and 36.2 psu near Cape St. Vincent and at $41^{\circ} \mathrm{N}$, respectively. This would therefore suggest that the observed meddies have detached from the slope downstream of Portimao Canyon, but south of $41^{\circ} \mathrm{N}$, which is admittedly not very restrictive. Meddy A was observed at $36^{\circ} 25^{\prime} \mathrm{N}, 12^{\circ} 20^{\prime} \mathrm{W}$, at the western end of Gorringe Bank at a saddle $3990 \mathrm{~m}$ deep connecting the Tagus and Horseshoe Abyssal Plains. This position and the general south (west) ward migration of meddies (Richardson et al. 1989) renders most likely a formation of this vortex in the Tagus Abyssal Plain, rather than south of Cape St. Vincent.

The meddy contribution to the total Mediterranean salt along the Bord-Est line was computed from the curve of Fig. 8 a to $18 \%$, or $24 \%$ if station 55 is added. A particular meddy at this longitude would therefore account for about $6 \%$ of the total. Estimating their contribution to the westward salt transport requires additional velocity informations that are more uncertain. Richardson et al. (1989) having tracked three meddies with SOFAR floats during year-long periods, found mean westward velocity components from 0.5 $\mathrm{cm} \mathrm{s}^{-1}$ to $2 \mathrm{~cm} \mathrm{~s}^{-1}$. Now, the velocity associated with the MW not contained in meddies may be deduced from Fig. 12. Using the ZF solution, which predicts westward flows throughout the MW domain of influence, leads to a typical value of $0.2 \mathrm{~cm} \mathrm{~s}^{-1}$. Then assuming that $80 \%$ of the Mediterranean salt content at the Bord-Est longitude is being transported westward at this velocity, and the remaining $20 \%$ is being advected in meddies at an average velocity of $1 \mathrm{~cm} \mathrm{~s}^{-1}$, the meddy contribution to the salt transport at this longitude would reach $55 \%$. Although this is but a very rough figure based on a single hydrographic realization and uncertain velocities, it is confirmation of the important meddy contribution to the salt budget of the large-scale MW plume.

\section{Conclusions}

We tried in this study to point out the connections between the distribution of the water masses and that of the zonal velocity along the eastern boundary of the North Atlantic. The region around $52^{\circ} \mathrm{N}$, which was described as the boundary between several water masses, also separates the particular circulation regime of Rockall Channel from that of the subtropical domain. In Rockall Channel the upper homogeneous water shows a basic anticyclonic circulation opposite to the cyclonic flow of the LSW below. The subtropical domain is dominated at its upper levels by an eastward transport of the NACW, but a westward return flow prevails south of $25^{\circ} \mathrm{N}$ in the region influenced by SACW. At intermediate levels a similar westward flow marks the presence of a fraction of AAIW south of $32^{\circ} \mathrm{N}$. The flow pattern associated with the MW is not so plain, as westward velocities only exist at $1000 \mathrm{db}$ between $38^{\circ} \mathrm{N}$ and $45^{\circ} \mathrm{N}$. This could be an indication that advection rules the westward injection of $\mathrm{MW}$ in this latitudinal band, while turbulent diffusion would be dominant elsewhere. Several meddies were indeed sampled south of $37^{\circ} \mathrm{N}$, and a rough computation showed that their contribution to the westward transport of Mediterranean salt could exceed $50 \%$. At the deepest levels the Bord-Est line reveals the bowl-shaped signature of the AABW isopycnals, particularly pronounced in the northern half of the basin, and associated with the general cyclonic flow of this water mass. 
Although this was not discussed in the previous sections, it is worth remarking other relations between the meridional distribution of the zonal transport and that of the annual wind forcing: the aforementioned region around $52^{\circ} \mathrm{N}$ is that of vanishing Ekman pumping, and the latitude where the transport reverses sign in the NACW $\left(\sim 28^{\circ} \mathrm{N}\right)$ is that of maximum downward Ekman pumping (Leetmaa and Bunker 1978). As a consequence, these key latitudes in the distribution of the zonal transport in our upper layer match their homologues of the classical wind-driven Sverdrupian models.

In budgeting the flows in and out of the eastern boundary, we cast a particular attention to the question of occanic ventilation. Sinking of incoming surface water at the eastern boundary, and subsequent reinjection in the ocean interior at deeper levels, has been either assumed or predicted in several analytical or numerical studies (Pedlosky 1983; Huang 1990; Colin de Verdière 1989). Although the downward entrainment of upper water with the MW outflow in the Gulf of Cadiz is a particular form of this mechanism, called "eastern boundary ventilation," our budget of the volume transport in the Central Water density range (layer 1) showed no other evidence of that process. On the other hand, a significant transport was shown to escape from the winter mixed layer (layer 6) at its easternmost longitudes to ventilate the gyre interior. Lateral transfer across the sloping bottom of the mixed layer should be mainly responsible for this transport, as southward alongshore flows were found east of the Bord-Est line over most of the subtropical domain. The important decrease of the mixed layer thickness from $45^{\circ}$ to $40^{\circ} \mathrm{N}$ suggests this region to be particularly efficient for the ventilation of the ocean thermocline. North of $45^{\circ} \mathrm{N}$ the Bord-Est line went through several anticyclonic mesoscale structures that appear as privileged sites of winter convection. The existence of these vortices raises the questions of their formation and contribution to the maintenance of the large-scale pool of low potential vorticity-or mode water-characteristic of the upper levels of the eastern basin at these latitudes.

Acknowledgments. The authors were supported during this investigation by the IFREMER Grant 210160 . The XBT measurements were carried out by the EPSHOM (Etablissement Principal du Service Hydrographique et Océanographique de la Marine), which also provided further support for the data analysis through Contract 87-473. Useful discussions with several colleagues, and the aid of C. Fontaine, C. Lagadec, $\mathrm{J}$. Le Gall, and J. Kervella in the preparation of this manuscript, are acknowledged.

\section{REFERENCES}

Arhan, M., A. Billant, A. Colin de Verdière, N. Daniault, and R. Prego, 1991a: Hydrography and velocity measurements offshore from the Iberian Peninsula. BORD-EST Data Report, Vol. 2,
Campagnes Océanographiques Françaises, No. 15, IFREMER, $232 \mathrm{pp}$.

,,,--- L. Mémery, and P. Tréguer, 1991b: CTD-O $\mathrm{O}_{2}$ and nutrients along the eastern boundary of the North-Atlantic Ocean from $60^{\circ} \mathrm{N}$ to $20^{\circ} \mathrm{N}$. BORD-EST Data Report, Vol. 1, Campagnes Océanographiques Françaises, No. 13, IFREMER, 115 pp.

Barton, E. D., 1987: Meanders, eddies and intrusions in the thermohaline front off Northwest Africa. Oceanol. Acta, 10, 267283.

- - , and A. E. Hill, 1989: Abyssal flow through the Amirante Trench (western Indian Ocean). Deep-Sea Res., 36, 1121-1126.

Bubnov, V. A., 1968: Intermediate subarctic waters in the northern part of the Atlantic Ocean (in Russian). Okeanologia, 19, 136153. [English translation (N00 Trans 545), U.S. Naval Oceanographic Office, Washington, DC 1973.]

Colin de Verdière, A., 1989: On the interaction of wind and buoyancy driven gyres. J. Mar. Res., 47, 595-633.

- H. Mercier, and M. Arhan, 1989: Mesoscale variability transition from the western to the eastern Atlantic along $48^{\circ} \mathrm{N}$. $J$. Phys. Oceanogr., 19, 1149-1170.

Cox, M. D., and K. Bryan, 1984: A numerical model of the ventilated thermocline. J. Phys. Oceanogr., 14, 674-687.

Dickson, R. R., W. J. Gould, T. J. Müller, and C. Maillard, 1985: Estimates of the mean circulation in the deep (>2000 m) layer of the eastern North Atlantic. Progress in Oceanography, Vol. 14, Pergamon, 103-127.

Ellett, D. J., 1980: Long-term water mass variations in the northeastern Atlantic. ICES CM 1980/c:9, 18 pp.

_- 1991: Norwegian Sea deep water overflow across the WyvilleThomson Ridge during 1987-88. ICES CM 1991/c:41, 11 pp.

—, and J. H. Martin, 1973: The physical and chemical oceanography of the Rockall Channel. Deep-Sea Res., 20, 585-625.

- - A. Edwards, and R. Bowers, 1986: The hydrography of the Rockall channel-an overview. Proc. Roy. Soc. Edinburgh, 88B, $61-81$.

Fiekas, V., J. Elken, T. Müller, A. Aitsam, and W. Zenk, 1992: A view of the Canary Basin thermohaline circulation in winter. $J$. Geophys. Res., 97(C8), 12 495-12 510.

Harvey, J., 1982: $\theta-S$ relationship and water masses in the eastern North-Atlantic. Deep-Sea Res., 29, 1021-1033.

Hendry, R., 1989: Hydrography measurements from C.S.S. Hudson Cruise 82-002. Canadian Tech. Report of Hydrography and Ocean Sciences, No. 118, $112 \mathrm{pp}$.

Howe, M. R., M. I. Abdullah, and S. Deetae, 1974: An interpretation of the double $T-S$ maxima in the Mediterranean outflow using chemical tracers. J. Mar. Res., 32, 377-386.

Huang, R. X., 1989: The generalized eastern boundary conditions and the three-dimensional structure of the ideal fluid thermocline. J. Geophys. Res., 94(C4), 4855-4865.

- 1990: On the three-dimensional structure of the wind driven circulation in the North-Atlantic. Dyn. Atmos. Oceans, 15, 117159.

Hughes, P., and E. D. Barton, 1974: Stratification and water mass structure in the upwelling area off Northwest Africa in April/ May 1969. Deep-Sea Res., 21, 611-628.

Huthnance, J. M., 1986: The Rockall slope current and shelf-edge processes. Proc. Roy. Soc. Edinburgh, 88B, 83-101.

Isemer, H. J., and L. Hasse, 1987: The Bunker Climate atlas of the North-Atlantic Ocean. Ber. Inst. Meereskd. Christian-AlbrechtsUniv., Kiel, 160A.

Krauss, W., and R. H. Käse, 1984: Mean circulation and eddy kinetic energy in the Eastern North Atlantic. J. Geophys. Res., 89(C3), $3407-3415$.

Leetmaa, A., and A. F. Bunker, 1978: Updated charts of the mean annual wind stress, convergences in the Ekman layers, and Sverdrup transports in the North Atlantic. J. Mar. Res., 36, 311-322.

Luyten, J. R., J. Pedlosky, and H. Stommel, 1983: The ventilated thermocline. J. Phys. Oceanogr., 13, 292-309. 
Madelain, F., 1967: Etude hydrologique au large de la Péninsule lbérique. Cah. Océanogr., 19(2), 125-136.

__, 1970: Influence de la topographie du fond sur l'écoulement méditerranéen entre le Détroit de Gibraltar et le Cap St. Vincent. Cah. Océanogr., 22, 43-63.

Maillard, C., 1986: Atlas hydrologique de l'Atlantic Nord-Est. Publications IFREMER, 133 plates.

McCartney, M. S., 1992: Recirculating components to the deep boundary current of the Northern North-Atlantic. Prog. Oceanogr., Vol. 29, Pergamon, 283-383.

- , and L. Talley, 1984: Warm to cold water conversion in the northern North Atlantic Ocean. J. Phys. Oceanogr., 14, 922935.

- - S. L. Bennett, and M. E. Woodgate-Jones, 1991: Eastward flow through the Mid-Atlantic Ridge at $11^{\circ} \mathrm{N}$ and its influence on the abyss of the eastern basin. J. Phys. Oceanogr., 21, 10891121.

Minas, H. J., B. Coste, P. Le Corre, M. Minas, and P. Raimbault, 1991: Biological and geochemical structures associated with the water circulation through the straits of Gibraltar and in the western Alboran Sea. J. Geophys. Res., 96(C5), 8755-8771.

Mittelstaedt, E., 1983: The upwelling area off Northwest Africa-A description of phenomena related to coastal upwelling. Progress in Oceanography, Vol. 12, Pergamon, 307-331.

Munk, W. H., 1966: Abyssal Recipes. Deep-Sea Res., 13, 707-730.

Pedlosky, J., 1983: Eastern boundary ventilation and the structure of the thermocline. J. Phys. Oceanogr., 13, 2038-2044.

Pingree, R. D., 1973: A component of Labrador Sea Water in the Bay of Biscay. Limnol. Oceanogr., 18, 711-718.

- , and B. Le Cann, 1992: Three anticyclonic slope water oceanic eddies (SWODDIES) in the southern Bay of Biscay in 1990. Deep-Seal Res., 39, 1147-1175.

Pollard, R. T., and S. Pu, 1985: Structure and circulation of the upper Atlantic Ocean northeast of the Azores. Progress in Oceanography, Vol. 12, Pergamon, 443-462.

Richardson, P. L., 1993: A census of eddies observed in North Atlantic SOFAR float data. Progress in Oceanography, Vol. 31, Pergamon, 1-5.

—-, D. Walsh, L. Armi, M. Schröder, and J. F. Price, 1989: Tracking three meddies with SOFAR floats. J. Phys. Oceanogr., 19, $371-$ 383.

Robinson, M. K., R. A. Bauer, and E. H. Schröder, 1979: Atlas of North Atlantic-Indian Ocean Monthly Mean Temperatures and
Mean Salinities of the Surface Layer. Naval Oceanography Office Ref. Pub. 18.

Saunders, P., 1987: Flow through Discovery Gap. J. Phys. Oceanogr., $17,631-643$

Schmitt, R. W., P. S. Bogden, and C. E. Dorman, 1989: Evaporation minus precipitation and density fluxes for the North Atlantic. J. Phys. Oceanogr., 19, 1208-1221.

Shaffer, G., 1976: A mesoscale study of coastal upwelling variability of NW Africa. "Meteor" Forschungsergeb. (A), 17, 21-72.

Siedler, G., A. Kuhl, and W. Zenk, 1987: The Madeira Mode Water. J. Phys. Oceanogr., 17, 1561-1570.

Stommel, H., 1979: Determination of water mass properties of water pumped down from the Ekman layer to the geostrophic flow below. Proc. Natl. Acad. Sci., 76, 3051-3055.

_ and A. B. Arons, 1960: On the abyssal circulation of the world ocean. I-Stationary planetary flow patterns on a sphere. DeepSea Res., 6, 140-154.

_- J. Meincke, and W. Zenk, 1977: New animals for the eddy zoo. Polymode New's, 22, 1 p., 3 figs.

Stramma, L., 1984: Geostrophic transport in the warm water sphere of the eastern subtropical North Atlantic. J. Mar. Res., 42, 537558.

Talley, L. D., and M. S. McCartney, 1982: Distribution and circulation of Labrador Sea Water. J. Phys. Oceanogr., 12, 1189 1205.

Tomczak, M., and P. Hughes, 1980: Three dimensional variability of water masses and currents in the Canary upwelling region. "Meteor" Forschungsergeb. (A), 21, 1-24.

Veronis, G., 1973: Model of World Ocean circulation: I-Wind-driven, two-layer. J. Mar. Res., 31, 228-288.

Williams, R., 1989: The influence of air-sea interaction on the ventilated thermocline. J. Phys. Oceanogr., 19, 1255-1267.

Wooster, W. S., A. Bakun, and D. R. McLain, 1976: The seasonal upwelling cycle along the eastern boundary of the North Atlantic. J. Mar. Res., 34, 131-141.

Worthington, L. V., 1976: On the North Atlantic Circulation. Johns Hopkins Oceanographic Studies, Vol. 6, The Johns Hopkins University Press, $110 \mathrm{pp}$.

Zenk, W., 1975: On the Mediterranean outflow west of Gibraltar. "Meteor" Forschungsergeb., 16, 23-34.

- , and L. Armi, 1990: The complex spreading pattern of Mediterranean Water off the Portuguese continental slope. Deep-Sea Res., 37, 1805-1823.

- B. Klein, and M. Schröder, 1991: Cape Verde Frontal Zone. Deep-Sea Res., 38(Suppl. 1), 5505-5530. 